\title{
Patterns and drivers for wetland connections in the Prairie Pothole Region, United States
}

\author{
Melanie K. Vanderhoof $(\mathbb{D} \cdot$ Jay R. Christensen $\cdot$ Laurie C. Alexander
}

Received: 25 March 2016/ Accepted: 5 November 2016/Published online: 19 November 2016

(C) The Author(s) 2016. This article is published with open access at Springerlink.com

\begin{abstract}
Ecosystem function in rivers, lakes and coastal waters depends on the functioning of upstream aquatic ecosystems, necessitating an improved understanding of watershed-scale interactions including variable surface-water flows between wetlands and streams. As surface water in the Prairie Pothole Region expands in wet years, surface-water connections occur between many depressional wetlands and streams. Minimal research has explored the spatial patterns and drivers for the abundance of these connections, despite their potential to inform resource management and regulatory programs including the U.S. Clean Water Act. In this study, wetlands were identified that did not intersect the stream network, but were shown with Landsat images (1990-2011) to
\end{abstract}

M. K. Vanderhoof $(\bowtie)$

Geosciences and Environmental Change Science Center, U.S. Geological Survey, DFC, MS980, 25046, Lakewood, CO 80225, USA

e-mail: mvanderhoof@usgs.gov

\section{J. R. Christensen}

Office of Research and Development, National Exposure Research Laboratory, Environmental Science Division, U.S. Environmental Protection Agency, 944 E. Harmon Ave.,, Las Vegas, NV 89119, USA

L. C. Alexander

Office of Research and Development, National Center for Environmental Assessment, U.S. Environmental Protection Agency, 1200 Pennsylvania Ave. NW (8623P), Washington, DC 20460, USA become merged with the stream network as surface water expanded. Wetlands were found to spill into or consolidate with other wetlands within both small (2-10 wetlands) and large ( $>100$ wetlands) wetland clusters, eventually intersecting a stream channel, most often via a riparian wetland. These surface-water connections occurred over a wide range of wetland distances from streams (averaging $90-1400 \mathrm{~m}$ in different ecoregions). Differences in the spatial abundance of wetlands that show a variable surface-water connection to a stream were best explained by smaller wetland-to-wetland distances, greater wetland abundance, and maximum surface-water extent. This analysis demonstrated that wetland arrangement and surface water expansion are important mechanisms for depressional wetlands to connect to streams and provides a first step to understanding the frequency and abundance of these surface-water connections across the Prairie Pothole Region.

Keywords Wetlands - Prairie Pothole Region . Connectivity $\cdot$ Network $\cdot$ Landsat $\cdot$ Wetland regulation

\section{Introduction}

Depressional wetlands provide critical hydrological services including storing precipitation and hydrologic inflows (Winter and Rosenberry 1998), which reduces peak stream flows and potential downstream flooding (Vining 2002; Yang et al. 2010). As depressional 
wetlands are typically non-channel connected (Tiner 2003), surface-water connections with other water bodies are usually not continuous. Under wet conditions, however, many of these wetlands cyclically or episodically exchange or contribute water to other wetlands, open waters, and/or streams through temporary overland or shallow groundwater flows, unmapped ditches or channels, and/or the merging of wetland waters in low relief areas (Rains et al. 2006, 2008; Cook and Hauer 2007; Sass and Creed 2008; Kahara et al. 2009; Wilcox et al. 2011; McCauley et al. 2015). During flood events or wet periods, depressional wetlands that become connected to streams or subsumed by lakes exchange water and materials, but may experience the temporary loss of wetland function until water levels recede (Junk et al. 1989; Galat et al. 1998; Mortsch 1998). Understanding landscape drivers for the abundance of wetlands that cyclically or variably contribute water to streams is important for accurately predicting stream flow, particularly during high flow events (Vining 2002; Yang et al. 2010), as well as informing the process to determine the jurisdictional status of wetlands in compliance with the U.S. Clean Water Act. Yet, relatively little research into variable surface-water connections, in particular landscape patterns and drivers of such connections, has been done (U.S. EPA 2015).

The Prairie Pothole Region (PPR), in northcentral North America, is known for its high density of depressional wetlands (Sorensen et al. 1998). Substantial variation in surface-water extent in response to climate is well-documented within the region (Beeri and Phillips 2007; Zhang et al. 2009; Niemuth et al. 2010; Huang et al. 2011a; Liu and Schwartz 2011). Changes to surface waters can result in variable wetland-to-wetland (Winter and Rosenberry 1998; Kahara et al. 2009) and wetlandto-stream connectivity (Leibowitz and Vining 2003; Sass and Creed 2008; Vanderhoof et al. 2016). Minimal research, however has sought to explain the abundance of wetlands that show variable surfacewater connections, or understand at a landscapescale how these wetlands consolidate and become connected to streams.

The primary metric used to identify wetlands that may lack a surface-water connection has been landscape position. This metric has been quantified using variables such as feature density, area, proximity, and cohesion, (Kahara et al. 2009) or distance to stream (Tiner 2003; Lang et al. 2012; Lane and D'Amico 2016). However, most of these efforts have been theoretical and have not related dynamic spatial variables, such as distance, to changes in actual surface-water extent. In addition to landscape position, the probability of connectivity for an individual wetland can also be expected to depend on climate, which influences the magnitude, frequency and duration of water inputs (Phillips et al. 2011); topography, which influences the capacity for surface-water expansion (Rover et al. 2011; Shaw et al. 2013); and anthropogenic drainage (i.e., ditches and tile drainage), which modifies topographical flows of surface water (McCauley et al. 2015). Although existing research has contributed to our ability to predict fill-and-spill on the scale of individual wetlands (Huang et al. 2011b) and in small, heavily instrumented watersheds (Shaw et al. 2012; Spence and Phillips 2014), efforts to understand the abundance of surface-water connections on a landscape scale have been minimal.

In this study, we identified wetlands that became connected to a stream in at least one of 16-17 Landsat images (acquired between 1990 and 2011) as surface-water extent expanded. Vanderhoof et al. (2016) quantified and examined temporal variability from drought to deluge, in surface-water connections between wetlands and streams in the PPR. In this study we eliminated the temporal aspect and instead investigated spatial landscape patterns related to the abundance of variable surface-water connections, exploring specifically, (1) the spatial mechanism and wetland cluster size through which wetlands merge with streams in wet years, (2) patterns in distance metrics for variably connected wetlands in relation to streams, and (3) landscape variables influencing the spatial abundance of these variably connected wetlands. This study builds upon previous work by evaluating the performance of simple distance metrics and investigating the use of landscape-scale parameters to explain variation in the abundance of surface-water connections within a region. Improved understanding of the drivers for the abundance of wetlands that cyclically or episodically contribute water to streams has implications for hydrological predictions as well as water resource management and policy. 


\section{Methods}

The per-pixel fraction water was derived for Landsat imagery using a partial unmixing algorithm. Aerial imagery from multiple dates was then used to (1) threshold the continuous fraction water into water and upland cover types, and (2) validate the Landsatderived maps of surface-water extent using a random point analysis. The Landsat-derived surface water maps were overlaid with wetland and stream reference datasets to identify a class of variabily connected (VC) wetlands, i.e., wetlands that became connected to a stream in at least one of the images as surface-water extent expanded. Wetland cluster size, mechanism of connection to a stream, and distance to stream for this class of wetlands were compared across six ecoregions. Lastly, the relative importance of explanatory variables was assessed to identify landscape factors influencing the abundance of wetlands in this class across the study area.

\section{Study area}

Ecoregions $(n=6)$ (Omernik and Griffith 2014) and 10-digit hydrological units (HUC10) $(\mathrm{n}=155)$ (Seaber et al. 1987) were used as the units of analysis across two, non-adjacent, Landsat path/rows [p29r29 (southern path/row) and p31r27 (northern path/row)] within the United States portion of the PPR (Fig. 1). The ecoregions included in this study represent a diversity of physiographic regions (Table 1) but were not intended to capture all possible variation that might occur in the PPR from Montana east to the Red River Valley, south into Iowa and north into Alberta and Saskatchewan. Ecoregion extent was modified from the U.S. Environmental Protection Agency Level IV Ecoregion definitions (Omernik and Griffith 2014), and included (1) Lowlands (included the Big Sioux Basin, James River Lowland and Loess Prairie ecoregions),(2) Des Moines Lobe (included the Minnesota River Prairie and Tewaukon/Big Stone Stagnation Morraine ecoregion), (3) Prairie Coteau, (4) Missouri Coteau, (5) Drift Plains, and (6) Devils Lake (Fig. 1; Table 1). HUC10 s were used as the unit of analysis (Seaber et al. 1987) for the modeling component of the study (Fig. 1). Land cover across the study area is dominated by cultivated crops $(56 \%)$, hay/pasture (13\%) and herbaceous vegetation (14\%) (Homer et al. 2015). Average summer (June-August, $20.5^{\circ} \mathrm{C}$ ) and winter (December-February, $-8.6{ }^{\circ} \mathrm{C}$ ) temperatures (1981-2010) are similar across the study area, while mean annual precipitation (1981-2010) is lower in the northern path/row (496 $\mathrm{mm} \mathrm{yr}^{-1}, 37 \mathrm{~mm}$ winter, $119 \mathrm{~mm}$ spring, $228 \mathrm{~mm}$ summer, and $112 \mathrm{~mm}$ fall', relative to the southern path/row $\left(649 \mathrm{~mm} \mathrm{yr}^{-1}\right.$, $40 \mathrm{~mm}$ winter, $175 \mathrm{~mm}$ spring, $273 \mathrm{~mm}$ summer, $161 \mathrm{~mm}$ fall) (NOAA NCDC 2014).

Image processing

Landsat images were selected to coincide with snowfree conditions and restricted to images with $<10 \%$ cloud cover. Cloud-free spring images were utilized when available to capture seasonal peaks in surfacewater extent post-snowmelt. Seventeen and sixteen images were included for the southern and northern path/rows, respectively. The images included conditions characterized as the $99 \%$ wettest by the monthly Palmer Hydrological Drought Index (PHDI), calculated from precipitation and temperature station data and interpolated at $5 \mathrm{~km}$ (NOAA NCDC 2014) (Table 2). Images were atmospherically corrected and converted to surface reflectance values using the Landsat Ecosystem Disturbance Adaptive Processing System (Masek et al. 2006). The Matched Filtering algorithm, a partial unmixing method in the ENVI software package (Exelis Visual Information Solutions, Inc, Herndon, Va) was used to produce the per pixel water fraction and classify these outputs into water and upland cover classes (Turin 1960; Frohn et al. 2012). Error was reduced by applying a minimum noise fraction transformation to reduce noise (Green et al. 1988), linearly stretching output values to maximize category separability, and masking out impervious surfaces, defined as low, medium and high density development land cover types to reduce false positives (Homer et al. 2015).

Surface-water extent was defined as saturated soil (i.e., visibly wet soil often adjacent to open water features) or wetter (i.e., inundated or open water). The water-upland threshold was derived by distinguishing the mean fraction water for saturated soil (239 total points) from the mean fraction water for upland photosynthetic vegetation (183 total points) using data points visually classified from 1-m National Agricultural Imagery Program (NAIP) imagery from three dates per Landsat path/row (April 30, 2004, October 13, 2006 and October 8, 2010 for p29r29; July 1, 2004, 
Fig. 1 The distribution of the units of analysis including ecoregions $(\mathrm{n}=6)$ and HUC10 s $(\mathrm{n}=155)$ within the two Landsat path/row extents (p31r27, northern path/row, p29r29, southern path/row)

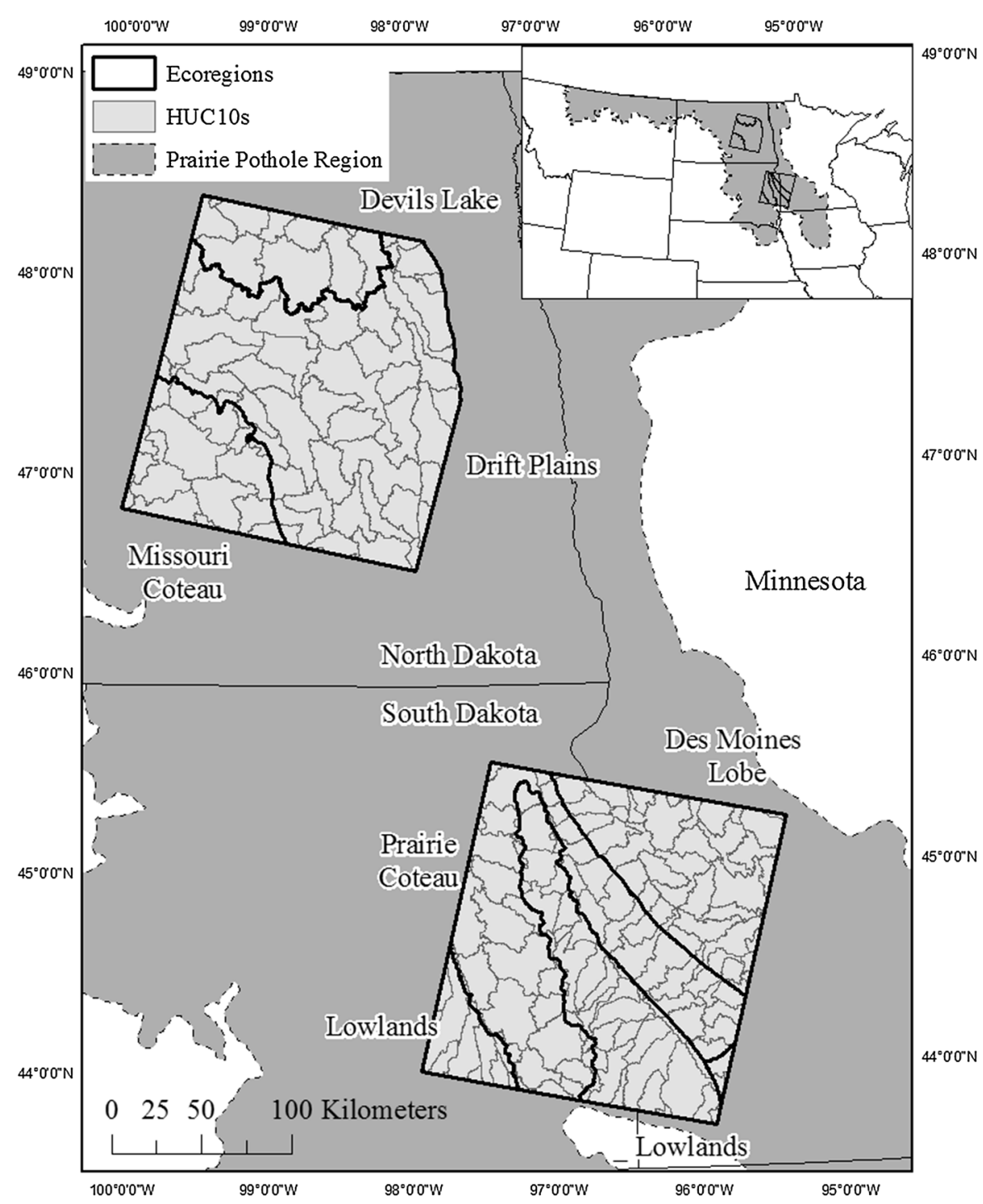

Validation analysis

October 5, 2004, and September 9, 2006 for p31r27). The derived threshold for water $(>0.26)$ was meant to include mixed pixels (e.g. shallow water or shallow sub-surface flow, wetland edges, and vegetated water) (e.g., Sass and Creed 2008). However, most small ( 3-10 m wide) channel-swale features (261 total points), which were also tested, represented a minor fraction of the Landsat pixel and were, on average, spectrally indistinguishable from upland photosynthetic vegetation and therefore unidentifiable. Differences in the fraction of water were larger between cover categories than between dates, so that the threshold was applied across all dates and both path/ rows. The outputs were surface-water extent maps.
The surface-water extent maps were validated using an independent data source, $1 \mathrm{~m}$ resolution NAIP imagery in a (1) random point analysis; and (2) minimum wetland size detection analysis. In the random point analysis, 1500 points (250 per Landsat path/row, same three NAIP dates per path/row as threshold analysis) were randomly selected. NAIP imagery was limited to images collected at dates similar to the Landsat imagery to minimize differences in surface-water extent between the two sources. Outcomes (surface water vs. upland) were visually compared between NAIP and the Landsat derived 
Table 1 Characteristics of ecoregions as derived from National Wetland Inventory (NWI) and National Hydrography Dataset (NHD) datasets

\begin{tabular}{llllllll}
\hline Ecoregion & Size (ha) & $\begin{array}{l}\text { Annual } \\
\text { Precipitation } \\
(1981-2010) \\
\text { Normal }(\mathrm{mm})\end{array}$ & $\begin{array}{l}\text { NHD stream } \\
\text { density } \\
\left(\mathrm{m} \mathrm{ha}^{-1}\right)\end{array}$ & $\begin{array}{l}\text { NWI wetland } \\
\text { area } \\
\left(\mathrm{m}^{2} \mathrm{ha}^{-1}\right)\end{array}$ & $\begin{array}{l}\text { NWI wetland } \\
\text { density } \\
(\# \text { per ha) })\end{array}$ & $\begin{array}{l}\text { Non-channel } \\
\text { connected NWI } \\
\text { wetlands }(\%)\end{array}$ & $\begin{array}{l}\text { Non-channel } \\
\text { connected NWI } \\
\text { wetland area }(\%)\end{array}$ \\
\hline Lowland & 887,232 & 653 & 13.4 & 485.3 & 0.06 & 80.0 & 40.0 \\
Des Moines Lobe & 824,612 & 648 & 10.1 & 616.6 & 0.02 & 83.4 & 31.6 \\
Prairie Coteau & 1215,080 & 646 & 9.7 & 1184.8 & 0.07 & 88.4 & 41.1 \\
Missouri Coteau & 524,552 & 484 & 3.0 & 1369.7 & 0.11 & 96.9 & 75.1 \\
Drift Plains & 1892,710 & 507 & 5.1 & 893.6 & 0.12 & 96.7 & 75.5 \\
Devils Lake & 443,718 & 507 & 1.8 & 2092.0 & 0.18 & 99.3 & 51.9 \\
\hline
\end{tabular}

Non-channel connected NWI wetlands are NWI wetlands that do not intersect the NHD stream buffer

Table 2 Landsat Thematic Mapper (TM) images utilized in the analysis and corresponding monthly Palmer Hydrological Drought Index (PHDI) values

\begin{tabular}{lllllr}
\hline Path/row & Landsat TM image & PHDI & Path/row & Landsat TM image & PHDI \\
\hline p29r29 & 10-May-90 & -3.55 & p31r27 & 9-Jun-90 & -4.12 \\
p29r29 & 13-May-91 & -0.69 & p31r27 & 12-Jun-91 & -2.45 \\
p29r29 & 15-May-92 & -1.15 & p31r27 & 27-Apr-92 & -1.93 \\
p29r29 & 23-Sep-93 & 6.86 & p31r27 & 26-Oct-94 & 7.03 \\
p29r29 & 15-Oct-95 & 6.37 & p31r27 & 27-Sep-95 & 5.97 \\
p29r29 & 14-Jun-97 & 4.02 & p31r27 & 14-Jul-97 \\
p29r29 & 30-Apr-98 & 2.77 & p31r27 & 1-May-99 & -0.09 \\
p29r29 & *8-May-01 & 4.47 & p31r27 & 9-Jul-01 & 2.01 \\
p29r29 & 19-Nov-02 & -1.69 & p31r27 & 5-Oct-04 & 4.46 \\
p29r29 & 28-Apr-03 & -2.01 & p31r27 & *18-Jun-05 & 4.38 \\
p29r29 & 1-Apr-05 & 3.15 & p31r27 & 9-Sep-06 & 1.45 \\
p29r29 & 4-Apr-06 & 4.2 & p31r27 & 12-Sep-07 & -2.91 \\
p29r29 & 13-Oct-06 & 2.3 & p31r27 & 1-Sep-09 & 2.41 \\
p29r29 & 15-Apr-10 & 5.43 & p31r27 & 6-Oct-10 & 3.28 \\
p29r29 & 8-Oct-10 & 9.63 & p31r27 & 5-Jul-11 & 6.43 \\
p29r29 & *5-Jun-11 & 8.37 & p31r27 & $* 11-S e p-11 ~$ & 6.61 \\
p29r29 & 11-Oct-11 & 5.88 & & & 8.92 \\
\hline
\end{tabular}

surface-water maps. Upland was defined as any pixel that did not meet the fraction of water threshold. Producer accuracy was the probability that a Landsat pixel was classified as surface water given that surface water was indicated by the NAIP imagery, while user accuracy was the probability that the NAIP imagery showed surface water being present given a Landsat pixel classified as surface water. Overall accuracy (percent of all points correctly classified) was $96.5 \%$. The producer accuracy for surface water was $94.6 \%$, while the user accuracy for surface water was $88.4 \%$ (Table 3). A threshold that allowed more mixed pixels or small wetland features, to be identified, produced a high producer accuracy (i.e., low omission error), but in turn reduced the user accuracy (i.e., introduced errors of commission) due to (1) limited confusion with the high leaf water content in dense agricultural fields in the Des Moines Lobe ecoregion, and (2) mixed-pixel or scale-related errors (e.g., NAIP image points located at the edge of features which resulted in a mixed Landsat pixel). To determine the minimum wetland size that was reliably detected, we randomly selected a total of 421 National Wetland Inventory (NWI) wetlands from the NAIP imagery that 
Table 3 Accuracy assessment for the surface water extent maps, comparing Landsat derived surface water and upland classification maps, to $1 \mathrm{~m}$ National Agricultural Imagery Program (NAIP) aerial imagery

\begin{tabular}{llrr}
\hline Map accuracy & NAIP-Wetland & NAIP-Upland & Total points \\
\hline Landsat-Wetland & 283 & 37 & 320 \\
Landsat-Upland & 16 & 1164 & 1180 \\
Total & 299 & 1201 & 1500 \\
Producer accuracy for wetland (\%) & 94.6 & & \\
User accuracy for wetland (\%) & 88.4 & & \\
Overall accuracy (\%) & 96.5 & & \\
Kappa statistic & 0.9 & & \\
\hline
\end{tabular}

were $<0.1$ ha to 1 ha in size. Wetlands were selected that (1) were individual wetland features (i.e., not part of a larger wetland cluster), and (2) showed at least some open water. Seventy nine percent of wetlands larger than 0.2 ha were reliably detected.

\section{Landscape analysis}

The NWI dataset (U.S. Fish and Wildlife Service, 2010) was used as the reference wetland dataset and was designed to represent wetland extent under "average" hydrological conditions (USFWS 2010). Stream occurrence was defined by the high resolution National Hydrography Dataset (NHD) (1:24,000) (USGS 2013). A stream buffer was applied $( \pm 14 \mathrm{~m}$ ) to account for the nationally reported digital accuracy of the lateral location of stream features within this dataset (USGS 2000). The stream/river NHDArea polygons were included to account for channel width. The NWI and NHD were used with additional datasets to derive landscape variables for assessing landscape influence on the abundance of surface-water connections. Lake count and total lake area were defined as the subset of NWI polygons classified as lacustrine $(0.4 \%$ of all NWI polygons in the study area). Maximum surface-water extent was derived from Landsat image showing the greatest surface-water extent (spring 2011 for both path/ rows) (Fig. 2). Change in surface-water extent was derived by subtracting the total surface-water extent from the driest image (spring 1990 for p29r29, spring 1991 for $\mathrm{p} 31 \mathrm{r} 27$ ) (ha), from the surface-water extent in the wettest image (spring 2011) (ha) (Fig. 2). Surface topography, which can influence the capacity for surface water to expand, was quantified as the (1) elevation coefficient of variation across each HUC10
(Ascione et al. 2008), as well as the (2) Melton ruggedness number, which is calculated as the maximum elevation minus the minimum elevation divided by the HUC10 area (Melton 1965), using the USGS National Elevation Dataset (NED) $10 \mathrm{~m}$ resolution (Gesch et al. 2002). Lastly, to account for anthropogenic modifications to drainage systems, the percent land cover artificially drained was estimated as the percent of each HUC with collocated row crop cover type (derived from the National Land Cover Database (NLCD) 2006) and very poorly drained or poorly drained soils as defined by the National Resources Conservation Service's SSURGO database (Christensen et al. 2013). The distribution of values within the explanatory variables are shown in Table 4 .

Wetland connectivity classification and mechanism for connection

"Surface-water connection" is used as a general term indicating multiple mechanisms, including wetland fill-and-spill, merging and subsuming of wetlands by lakes or other wetlands and stream overbank flow. In using this term, we make no assumption about shifts or loss of wetland function that co-occur with surfacewater expansion. The NWI wetlands were separated into three classes for this analysis, (1) wetlands which directly intersected the NHD stream layer (including stream polygons and buffer) and were considered to show a semi-permanent or permanent connection to a stream (SI or stream-intersect wetlands), (2) NWI wetlands which did not intersect the stream layer, but intersected a stream-connected patch of surface water, as mapped by Landsat in at least one of the Landsat images (VC or variably connected wetlands) (Fig. 2), and (3) NWI wetlands for which no stream connection 
Table 4 Explanatory variables and units considered by linear regression models

\begin{tabular}{|c|c|c|c|c|c|c|}
\hline Variables & Units & Range & $\begin{array}{l}25 \text { th } \\
\text { percentile }\end{array}$ & $\begin{array}{l}\text { 50th } \\
\text { percentile }\end{array}$ & $\begin{array}{l}\text { 75th } \\
\text { percentile }\end{array}$ & Source \\
\hline Stream density & $\begin{array}{l}\mathrm{km}^{-1} \\
\mathrm{ha}^{-1}\end{array}$ & $0.0011-0.021$ & 0.0037 & 0.0074 & 0.011 & $\begin{array}{l}\text { High Res. National Hydrograph } \\
\text { Dataset (NHD) (USGS 2013) }\end{array}$ \\
\hline $\begin{array}{l}\text { Wetland to stream } \\
\text { Euclidean distance }\end{array}$ & $\mathrm{m}$ & $55.58-3195.32$ & 306.73 & 520.64 & 1215.54 & High Res. NHD (USGS 2013) \\
\hline Lake abundance (count) & $\begin{array}{l}\text { no } \\
\mathrm{ha}^{-1}\end{array}$ & $0-0.0052$ & $0.00,059$ & 0.0012 & 0.0019 & $\begin{array}{l}\text { National Wetland Inventory } \\
\text { (USFWS 2010) }\end{array}$ \\
\hline Lake areal abundance & $\begin{array}{l}\text { ha } \\
\text { ha }^{-1}\end{array}$ & $0-0.92$ & 0.023 & 0.054 & 0.096 & $\begin{array}{l}\text { National Wetland Inventory } \\
\text { (USFWS 2010) }\end{array}$ \\
\hline $\begin{array}{l}\text { Maximum surface water } \\
\text { extent }\end{array}$ & $\begin{array}{l}\text { ha } \\
\text { ha }^{-1}\end{array}$ & $0.0091-0.41$ & 0.070 & 0.10 & 0.19 & Landsat images \\
\hline $\begin{array}{l}\text { Change in surface water } \\
\text { extent }\end{array}$ & $\begin{array}{l}\text { ha } \\
\text { ha }^{-1}\end{array}$ & $0.00,031-0.37$ & 0.037 & 0.067 & 0.13 & Landsat images \\
\hline Total wetland density & $\begin{array}{l}\text { no } \\
\mathrm{ha}^{-1}\end{array}$ & $0.0059-0.27$ & 0.032 & 0.076 & 0.12 & $\begin{array}{l}\text { National Wetland Inventory } \\
\text { (USFWS 2010) }\end{array}$ \\
\hline $\begin{array}{l}\text { Total wetland areal } \\
\text { abundance }\end{array}$ & ha ha ${ }^{-1}$ & $0.0032-0.26$ & 0.040 & 0.077 & 0.12 & $\begin{array}{l}\text { National Wetland Inventory } \\
\text { (USFWS 2010) }\end{array}$ \\
\hline $\begin{array}{l}\text { Wetland to wetland } \\
\text { Euclidean distance }\end{array}$ & $\mathrm{m}$ & $49.02-351.84$ & 69.32 & 88.13 & 128.30 & $\begin{array}{l}\text { National Wetland Inventory } \\
\text { (USFWS 2010) }\end{array}$ \\
\hline $\begin{array}{l}\text { Percent drained by } \\
\text { anthropogenic means }\end{array}$ & $\%$ & $0.15-60.06$ & 1.85 & 3.85 & 16.78 & $\begin{array}{l}\text { National Land Cover Database and } \\
\text { Soil Survey Geographic } \\
\text { Database (Christensen et al. } \\
\text { 2013) }\end{array}$ \\
\hline $\begin{array}{l}\text { Elevation coefficient of } \\
\text { variation }\end{array}$ & $\mathrm{m}$ & $5 E-08-0.23$ & 0.021 & 0.033 & 0.053 & $\begin{array}{l}\text { National Elevation Dataset (NED) } \\
10 \mathrm{~m} \text { Digital Elevation Model } \\
\text { (DEM) (Gesch et al. 2002) }\end{array}$ \\
\hline $\begin{array}{l}\text { Melton ruggedness } \\
\text { number }\end{array}$ & $\mathrm{m} \mathrm{km}^{2}$ & $0.17-3.43$ & 0.38 & 0.54 & 0.83 & $\begin{array}{l}\text { NED } 10 \text { m DEM }((Z \max -Z \min ) / \\
\text { area) (Gesch et al. 2002) }\end{array}$ \\
\hline
\end{tabular}

Range and percentiles are provided to show distribution of values for each variable across all hydrological units (HUC10s)

was observed in any of the Landsat images ( $\mathrm{NCO}$ or no connection observed wetlands) (Fig. 3). It is important to note that occasional or even frequent surface-water stream connections may also occur for wetlands included in the third category (NCO). Landsat imagery can be expected to bias the analysis towards surfacewater connections that occur through the expansion of relatively broad features such as river overflow into floodplains, or features merging or being subsumed from increases in water level or filling and spilling. Cyclical or episodic linear connections (e.g., ephemeral channels, swales, ditches) that connect some waters (e.g., Tromp-van Meerveld and McDonnell 2006) are often not well documented by NHD, which has been shown to inconsistently map such features (Lang et al. 2012; Fritz et al. 2013) and are difficult to detect with Landsat. Although this approach to observing all $\mathrm{VC}$ wetlands is limited due to a low probability of detecting narrow and/or short duration (hours to days) connections, it allows us to identify regionally relevant parameters that may influence the abundance of such wetlands in the PPR.

The mechanism through which $\mathrm{VC}$ wetlands connect to streams was also investigated. Most of the VC wetlands merged with streams only under deluge or very wet conditions. Therefore, to derive the distribution of VC wetlands by wetland cluster size (or a complex of surficially-connected wetlands or consolidated wetlands), the number of $\mathrm{VC}$ wetlands cooccurring within a single Landsat-derived surfacewater polygon was quantified using the two wettest (greatest percent area classified as inundated and 
saturated) images for each path/row (spring 2005 and 2011 for p31r27, spring 2001 and 2011 for p29r29) (Fig. 3). The mechanism of connection for VC wetlands was further classified as, (1) connecting through a wetland cluster containing a SI wetland, (2) connecting through individual expansion of a wetland and/or stream, or (3) connecting through a wetland cluster comprised only of VC wetlands. In cases in which a wetland was subsumed by adjacent streamconnected wetlands or a stream-connected lake, the wetland was considered to be "connected." Connection through an SI wetland was identified when an SI wetland co-occurred within a continuous Landsat polygon with VC wetlands. As lakes can occur as SI, VC or NCO features, connection through a lake was not specifically distinguished in this analysis. References to wetlands, therefore, could include water bodies specified by NWI as lakes or ponds.

\section{Euclidean and flowpath distance}

Euclidean and flowpath distances to stream were calculated for each VC and NCO wetland. Although many factors may influence individual wetland hydrology (e.g., water retention capacity, topography, flow characteristics), simple parameters such as distance can be appealing to decision-makers, who need "bright line boundaries" between policy categories (Alexander 2015). It is therefore worthwhile to consider correlations with easily-measured structural parameters. Euclidean distances were calculated from the nearest edge of the wetland to the edge of the stream buffer. Flowpath distance for each wetland to stream were derived using the USGS NED $10 \mathrm{~m}$ resolution (Gesch et al. 2002). The buffered stream layer was converted to raster, overlaid onto the DEMs and assigned a no-data value so that topographic flows would end at the stream buffer edge. The DEMs were filled so that flow direction for all elevation cells could be routed to the stream edge. Stream raster layers were converted to " 0 " values to allow for complete flow length and flow accumulation measurements and flow length was calculated from each wetland's "spill point," identified as the point on each wetland perimeter with the greatest flow accumulation value (Blaszczynski 1997). The distance analysis was performed using Esri ArcGIS 10.2 (Esri 2013) and Arc Hydro (Maidment 2002). Cumulative distribution functions, ANOVA and Tukey HSD post hoc tests, using log-transformed data, were run in $\mathrm{R}$ to investigate variation in mean distance between ecoregions (R Core Team 2014). Log-mean distances and 95\% confidence intervals were back-transformed to the original units (geometric means) when reported. In addition to tests of statistical significance, which are influenced by sample size, standardized mean differences (effect size, Cohen's d) among ecoregions were compared to thresholds in Cohen (1988) to interpret the magnitude of effects in pairwise comparisons of mean wetland distance to stream.

Variable importance assessment

Multiple regression and analysis of relative variable importance were used to quantify the contribution of the selected landscape variables to observed spatial variation in the abundance of derived wetland classes (VC, SI, and NCO). Regression assumptions were tested (R package car) (Fox and Weisberg 2011) and a Box-Cox power transformation (R package MASS, Venables and Ripley 2002) was applied to each of the dependent variables to correct for non-linearity and non-random distribution of residuals.

Each of the dependent variables (SI, VC, and NCO abundance) was found to be highly spatially autocorrelated, using Moran's I (SI, z-score $=12.7$, $\mathrm{p}<0.01, \quad \mathrm{VC}, \mathrm{z}$-score $=6.9, \mathrm{p}<0.01, \mathrm{NCO}, \mathrm{z}-$ score $=12.5, \mathrm{p}<0.01$ ), violating the assumption of independence. To account for this, an autocovariate was added that represented the area-weighted neighborhood response values of contiguous HUC10 polygons. By including a spatial autocovariate (e.g., Dormann et al. 2007; Betts et al. 2009) in the regression model, we control for how much the response variable reflects response values of adjacent HUCs, before identifying additional significant explanatory variables. Adding an autocovariate transforms the linear predictor of a generalized linear model from its usual form, $\mathrm{y}=\mathrm{X} \mid \beta+\varepsilon$, (1) to $\mathrm{y}=\mathrm{X} \beta+\mathrm{pA}+\varepsilon(2)$, where $\beta$ is a vector of coefficients for intercept and explanatory variables $X, p$ is the coefficient of the autocovariate $A$, and $\varepsilon$ is the vector of random errors. For the models tested the inclusion of an autocovariate removed the effect of spatial autocorrelation on the residuals (SI, z-score $=1.9, \quad \mathrm{p}=0.06, \quad \mathrm{VC}, \quad \mathrm{z}$-score $=0.3$, $\mathrm{p}=0.8, \mathrm{NCO}, \mathrm{z}$-score $=-1.1, \mathrm{p}=0.3$ ). Alternative methods to account for spatial autocorrelation were 
also tested (e.g., simultaneous autoregressive models) (R package, spdep) (Kissling and Carl 2008), but did not produce AIC values as low as when an autocovariate was used.

Multicollinearity was assessed using the regression collinearity diagnostics described by Belsley et al. (1980) and implemented in the $\mathrm{R}$ package perturb (Hendrickx 2012). Collinearity may affect parameter estimation when a condition index (CI) greater than 10 is associated with variance decomposition proportions (VDP) greater than 0.5 for two or more explanatory variables (Belsley 1991). For the models tested, independent variables representing maximum surface-water extent, change in surface water extent and areal wetland abundance were identified as highly correlated (CI 19 and VDP > 0.75). Change in surface-water extent (maximum-minimum) and areal wetland abundance were removed, as these variables were interpreted to be redundant with and less informative than maximum surface-water extent, and regression diagnostics including collinearity were re-run for the reduced models ( $\mathrm{CI}<7$ for all models).

Given the exploratory nature of this analysis, we compared four approaches for quantifying the relative contribution of the explanatory variables. In the first, the sum of Akaike weights provided the ratio of the change in AICc for each linear model that includes a specific variable to the whole set of possible linear models (R package, MuMIn) (Barton 2012). In the second, a hierarchical partitioning algorithm (Chevan and Sutherland 1991) was applied to the root-meansquare "prediction" error for all possible models to produce the independent (I) and conjoined (J) contribution of each variable (R package, hier.part) (Walsh and MacNally 2003; Murray and Conner 2009). Third, random forests were used (500 trees) and variable importance was calculated as the change in node impurity (Gini importance) ( $\mathrm{R}$ package, randomForest) (Liaw and Wiener 2015). Lastly we calculated conditional permutation variable importance derived from the cforest algorithm in R (500 trees), which is designed to reduce bias introduced by multicollinearity ( $\mathrm{R}$ package, party) (Strobl et al. 2008; Hothorn et al. 2015). The normalized results are presented to allow for the comparison of results across multiple tests. All statistical analyses were completed in R (R Core Team 2014) and the Global Moran's I tests were completed in ArcGIS 10.2.2 (ESRI 2013).

\section{Results}

Distance patterns of wetlands by class

The inclusion of several Landsat images from particularly wet years allowed us to identify a subset of wetlands that showed a variable connection to streams (Fig. 4). The percentage of wetlands classified as VC wetlands exceeded the percentage of SI wetlands in every ecoregion except the Lowlands (Table 5), and was almost double the percentage of SI wetlands across the entire study area. Wetlands classified as NCO, however, were the majority wetland class in all six ecoregions, ranging from $63.9 \%$ in the Des Moines Lobe to $92.4 \%$ in the Missouri Coteau (Table 5). Patterns in VC wetland distance to stream were evident, but substantially different between ecoregions (Fig. 4). $\mathrm{VC}$ wetlands occurred on average, closer to streams than NCO wetlands in each of the six ecoregions. However, the average distance an NCO wetland occurred in relation to a stream was smaller in the Lowlands, Des Moines Lobe and Prairie Coteau than the average distance that a $\mathrm{VC}$ wetland occurred from a stream in the Devils Lake ecoregion (Table 6; Fig. 4). Because Devils Lake water level expanded dramatically during periods of deluge, wetlands, previously long distances from the lake edge were subsumed, and therefore became part of a stream-connected lake. The distance over which this occurred was long relative to the other ecoregions, with a mean Euclidean distance of wetland to stream for $\mathrm{VC}$ wetlands of $1104 \mathrm{~m}$ (mean flowpath distance $=2466 \mathrm{~m}$ ) (Table 6; Fig. 4). Flowpath distance showed similar between-ecoregion patterns but were much greater relative to Euclidean distances (123-203\% greater for VC wetlands and 141-199\% greater for NCO wetlands, by ecoregion). Effect sizes were insensitive to distance measure (Euclidean vs. flowpath), so effect size results for Euclidean and flowpath were averaged by wetland class (NCO and VC) (Table 7). The magnitude of effect for distance to stream was largest for comparisons of other ecoregions with Devils Lake. Effect sizes for distance to stream were negligible between the Missouri Coteau and the Drift Plains, and between the Des Moines Lobe and Prairie Coteau, for both NCO and VC wetlands. Effect size of distance to stream was also negligible for NCO wetlands, but not for VC wetlands, between the Lowland, Des Moines Lobe and Prairie Coteau ecoregions (Table 7). 


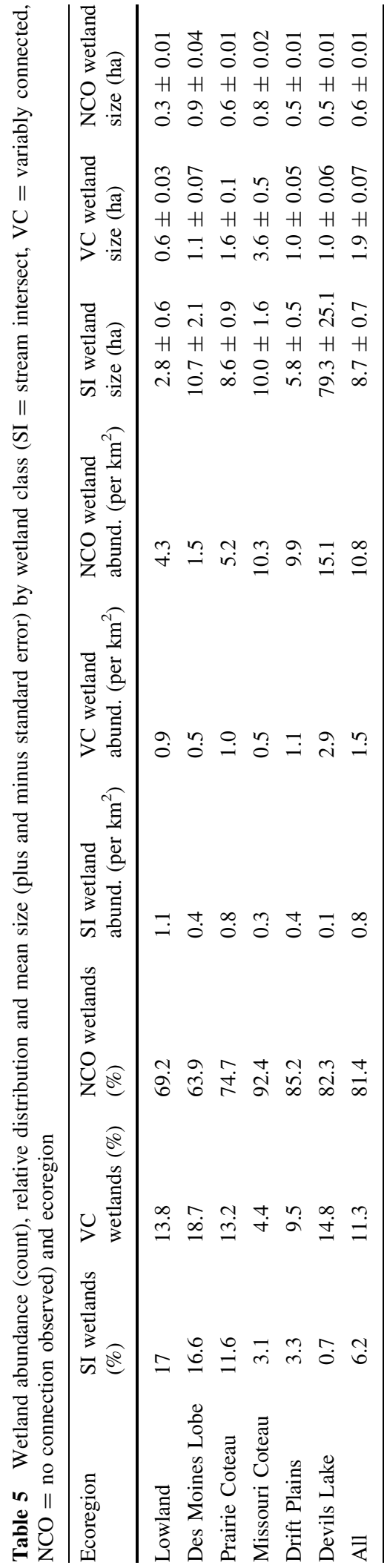

Mechanism of connection for $\mathrm{VC}$ wetlands

SI wetlands were found to play an important role in merging or consolidating VC wetlands (40-80\% across ecoregions) with streams (Table 8). The merging (or subsuming) of $\mathrm{VC}$ wetlands with one another and merging with streams, in a stepping-stone or consolidation manner, independent of SI wetlands also played a substantial role, connecting approximately $20-30 \%$ of VC wetlands in deluge conditions, depending on the ecoregion (Table 8). The importance of wetlands merging individually to streams (i.e., no stepping-stone activity), showed variable importance, but was particularly important in the Des Moines Lobe which contains the Minnesota River (connected almost $30 \%$ of the VC wetlands in this ecoregion) (Table 8). Wetland clusters (surficially connected or consolidated wetlands or the co-occurrence of more than one NWI wetland within a single Landsat surface-water extent polygon) of multiple size classes were found to be important in connecting VC wetlands to streams (Fig. 3). Across all ecoregions under deluge conditions, connected wetland clusters containing over 100 wetlands were found to contain the majority of the VC wetlands (37.7\%), however smaller wetland clusters (e.g., two to ten wetlands) were also found to be critical, containing $24.2 \%$ of VC wetlands (Fig. 5). The frequency of different sized wetland clusters also varied substantially between ecoregions. In the Des Moines Lobe, for example, most VC wetlands connected either individually $(29.4 \%)$, or through small clusters (2-10 VC wetlands) (41.2\%), while in Devils Lake ecoregion, $90.7 \%$ of the VC wetlands connected via wetland clusters with more than $100 \mathrm{VC}$ wetlands in the cluster (i.e., the expansion of Devils Lake) (Fig. 5).

Variable importance in explaining wetland class abundance

The abundance of wetland types (SI, VC, NCO) showed strong spatial patterns (Fig. 6). After controlling for the spatial autocorrelation of wetland abundance, increases in the abundance of SI wetlands were best explained by increases in stream density and smaller mean distances between wetlands and streams. These two variables were consistently important across all four approaches used to evaluate relative variable importance (Table 9). The abundance of 


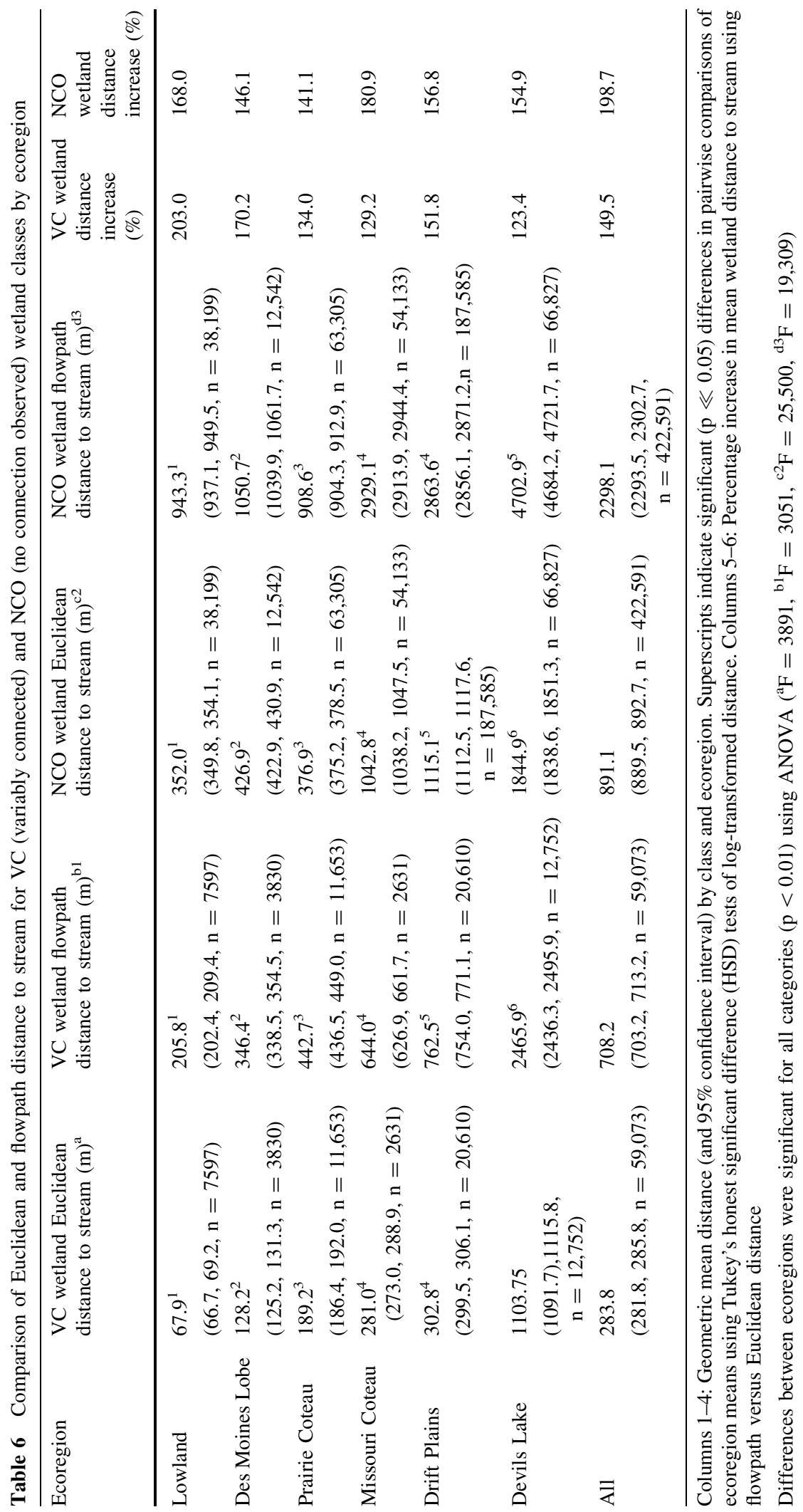




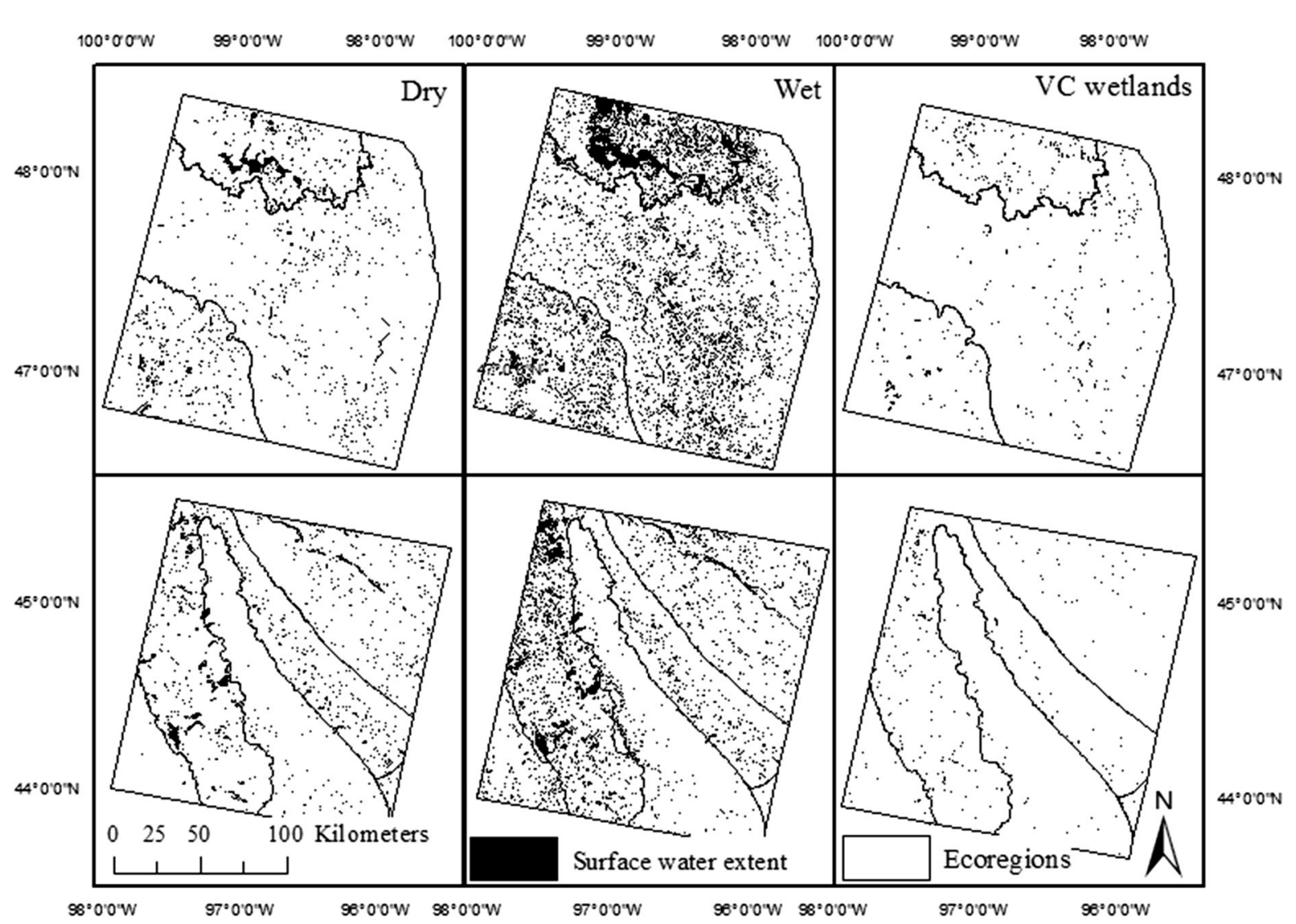

Fig. 2 Patterns of water cover (saturated) for dry $(\operatorname{Pr}(0.06)$ Cumulative distribution function (CDF)) Palmer Hydrological Drought Index (PHDI) (spring 1990) (left) and wet $(P r(0.99)$ CDF PHDI) (spring 2011) (middle) conditions for p31r27 (top row) and p29r29 (bottom row). The spatial distribution of variably connected (VC) National Wetland Inventory (NWI) wetlands is shown for both path/rows (right). note Most small wetlands are NOT visible due to the scale of the images

Table 7 Standardized mean differences in VC (variably connected) and NCO (no connection observed) wetland distance to stream

\begin{tabular}{|c|c|c|c|c|c|c|c|c|c|c|}
\hline & \multicolumn{2}{|l|}{ Lowland } & \multicolumn{2}{|c|}{ Des Moines Lobe } & \multicolumn{2}{|c|}{ Prairie Coteau } & \multicolumn{2}{|c|}{ Missouri Coteau } & \multicolumn{2}{|c|}{ Drift Plains } \\
\hline & $\mathrm{VC}$ & $\mathrm{NCO}$ & $\mathrm{VC}$ & $\mathrm{NCO}$ & $\mathrm{VC}$ & $\mathrm{NCO}$ & $\mathrm{VC}$ & $\mathrm{NCO}$ & $\mathrm{VC}$ & $\mathrm{NCO}$ \\
\hline Des Moines Lobe & 0.36 & 0.13 & & & & & & & & \\
\hline Prairie Coteau & $0.51 *$ & 0.04 & 0.15 & 0.13 & & & & & & \\
\hline Missouri Coteau & $0.74 *$ & $0.91 * *$ & 0.41 & $0.81 * *$ & 0.24 & $0.93 * *$ & & & & \\
\hline Drift Plains & $0.84 * *$ & $1.03 * *$ & 0.49 & $0.91 * *$ & 0.34 & $1.02 * *$ & 0.11 & 0.04 & & \\
\hline Devils Lake & $1.72 * * *$ & $1.51 * * *$ & $1.41 * * *$ & $1.48 * * *$ & $1.17^{* *}$ & $1.52 * * *$ & $0.98 * *$ & $0.51 *$ & $0.76^{*}$ & $0.48 *$ \\
\hline
\end{tabular}

Superscripts indicate effect size thresholds for pairwise comparisons of ecoregion means reported in Table 6. Effect sizes were not sensitive to distance measure so results for Euclidean and flowpath distance measures were averaged within wetland classes (VC, $\mathrm{NCO}$ )

Effect size: Very large $1.3^{\prime * * *}$ ' Large $0.8^{\prime * * *}$ ' Medium $0.5^{\prime *}$ ’ Small 0.2 '?' (Cohen 1988)

NCO wetlands were most highly correlated with wetland density (Table 9). However, because most wetlands across the study area were classified as NCO wetlands (Table 5), this explanatory variable was seen as uninformative. Similarly, wetland to wetland distance was highly correlated with wetland density $(\mathrm{R}=-0.95)$ and therefore also uninformative (Table 10). Variability in NCO wetland abundance was best explained by the percent of land that was drained by anthropogenic means. NCO wetland 
Table 8 Mechanism of connection for VC (variably connected) wetlands under deluge conditions, defined as the two wettest images per path/row

\begin{tabular}{llll}
\hline Ecoregion & $\begin{array}{l}\text { Merging } \\
\text { with SI } \\
\text { wetlands } \\
(\%)\end{array}$ & $\begin{array}{l}\text { Expansion of } \\
\text { individual } \\
\text { wetlands }(\%)\end{array}$ & $\begin{array}{l}\text { Expansion and } \\
\text { merging with } \\
\text { other VC } \\
\text { wetlands }(\%)\end{array}$ \\
\hline Lowland & 46.0 & 21.5 & 32.5 \\
Des Moines Lobe & 44.7 & 29.4 & 25.9 \\
Prairie Coteau & 60.2 & 17.7 & 22.1 \\
Missouri Coteau & 65.9 & 11.4 & 22.7 \\
Drift Plains & 54.8 & 12.1 & 33.1 \\
Devils Lake & 82.2 & 0.9 & 16.9 \\
All & 60.4 & 12.5 & 27.1
\end{tabular}

Expansion of individual wetlands refers to those expanded wetlands that connect directly to the stream layer. Merging with SI (stream intersect) wetlands refers to wetlands merging in a stepping-stone fashion with the end member an SI wetland. Expansion and merging with other VC wetlands refers to a similar stepping-stone merging, but with the end member the stream layer

abundance decreased as more of each HUC was artificially drained. This explanatory variable was consistently important across all four approaches. Stream density and wetland to stream distance were also ranked as important in more than one approach. $\mathrm{NCO}$ wetland abundance increased with lower stream density and larger mean wetland to stream distances. Lastly, total wetland density and wetland to wetland distance were identified as the most consistently important variables to explain variability in $\mathrm{VC}$ wetland abundance after controlling for spatial autocorrelation. Meanwhile, maximum surface water extent also ranked as an important variable in $\mathrm{VC}$ abundance by more than one approach. VC wetland abundance increased with more wetlands, located in close proximity to one another, and large maximum surface water extents during wet periods (Fig. 5).

\section{Discussion}

This study provides one of the first landscape-scale efforts to explore spatial patterns and landscape drivers of dynamic surface-water connections between depressional wetlands and streams in the PPR. These VC wetlands were found to connect to streams predominately through merging with and being subsumed by other wetland features. Both small (2-10) and large $(>100)$ wetland clusters (or complexes of surficially connected or consolidated wetlands) were common across the study area. The consolidation of wetlands was particularly common around lake features, many of which occur in open, flat basins in which excess water can result in $100 \%$ to almost $600 \%$ increases in surface-water extent (Vanderhoof and Alexander 2015) (Fig. 6). Initial rises in lake levels may merge wetlands with lakes, but wetlands may still retain wetland vegetation and function. However, as lake levels continue to rise, merged wetlands are completely subsumed by lakes and no longer function as independent depressional wetlands (Mortsch 1998). Features were observed to expand and contract in response to variable wetness conditions, connecting and disconnecting lakes, streams and wetlands. Previous work in the PPR documented variability in wetland-to-wetland and wetland-to-stream connectivity as surface water merges in low relief areas and/or wetlands fill and spill (Leibowitz and Vining 2003; Kahara et al. 2009; Shaw et al. 2013; Vanderhoof et al. 2016), and sought to predict connectivity based on storage capacity and spill point elevation (Huang et al. 2011b), temporal changes in surface-water extent (Rover et al. 2011), and wetland vegetation and water chemistry (Cook and Hauer 2007). This study sought to move from the prediction of connections for individual wetlands to explaining variability in the abundance of such surface-water connections on a landscape scale.

The probability of hydrologic connectivity has been most commonly linked to the proximity or distance between depressional wetlands and streams (Tiner 2003; Kahara et al. 2009; Lang et al. 2012). Yet this study found that substantial variation in the mean Euclidean and flowpath distance to stream for VC and $\mathrm{NCO}$ wetlands between ecoregions makes it extremely problematic to identify VC wetlands based on distance alone. For example within $400 \mathrm{~m}$ of a stream on the Des Moines Lobe, $78 \%$ of the VC wetlands were connected, while the Drift Plains had only 52\% of the VC wetlands connected at that same distance. Consequently while mean distance to stream emerged as an important variable in explaining the abundance of SI and NCO variables, it was not ranked as important in explaining the abundance of VC wetlands. Instead, for VC wetlands, wetland arrangement (wetland to 

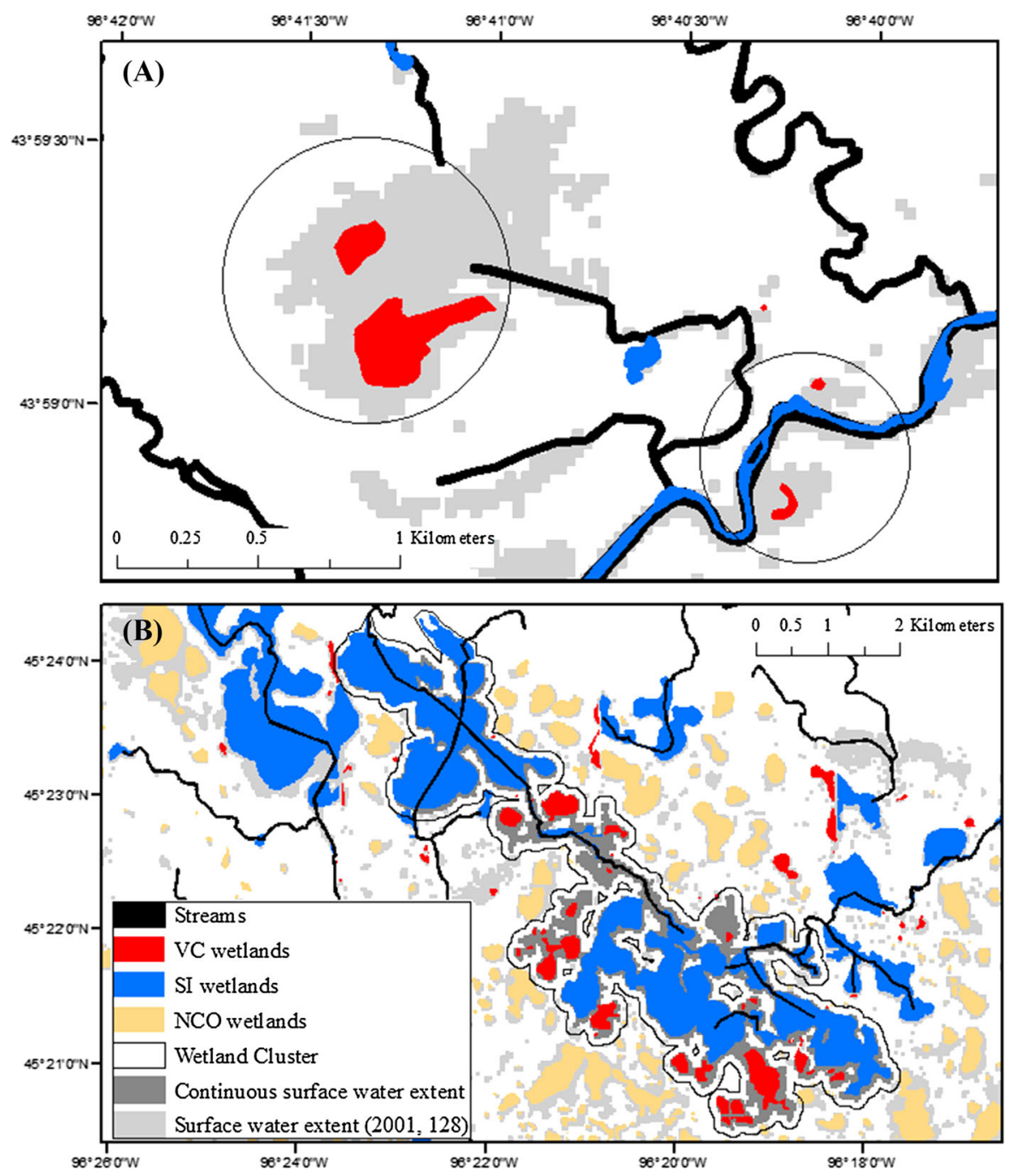

Fig. 3 Wetlands that showed a variable connection to streams (VC wetlands) occurred in clusters of varying size as shown by a $\mathrm{VC}$ wetlands connecting to a tributary of the Big Sioux River

wetland distance), as well as the temporal dynamics of surface-water expansion, also need to be considered. Additionally, in landscapes with little relief, flowpath distance from a fixed spill point to a fixed stream entry point may be less relevant. Surface flows connecting wetlands to streams in this area may not follow a single, theoretical flowpath, but instead are likely to expand and spread across the flat surface as excess water accumulates in a catchment.

The variables considered in the models represent several different factors in determining landscapescale connectivity including (1) wetland abundance, (2) wetland arrangement (distance variables), (3) the (left circle) and individually to the Big Sioux River (right circle), and b $32 \mathrm{VC}$ wetlands connecting within a continuous cluster to a tributary of the Minnesota River

availability of surface water connections (stream and lake abundance, surface water extent), and (4) potential influences on water accumulation and flow (topography and land use variables). However, across the PPR, variability within and between these variables is intrinsically tied to variability in landscape age (since last glacial retreat) and corresponding drainage development across the region (Ahnert 1996). The last maximum glacial extent (the Wisconsin glacier) diverged around the Lowlands ecoregion, leaving the older landscape (>20,000 BP) with a well-developed drainage network (Clayton and Moran 1982). In contrast, the Wisconsin glacier retreated from the 

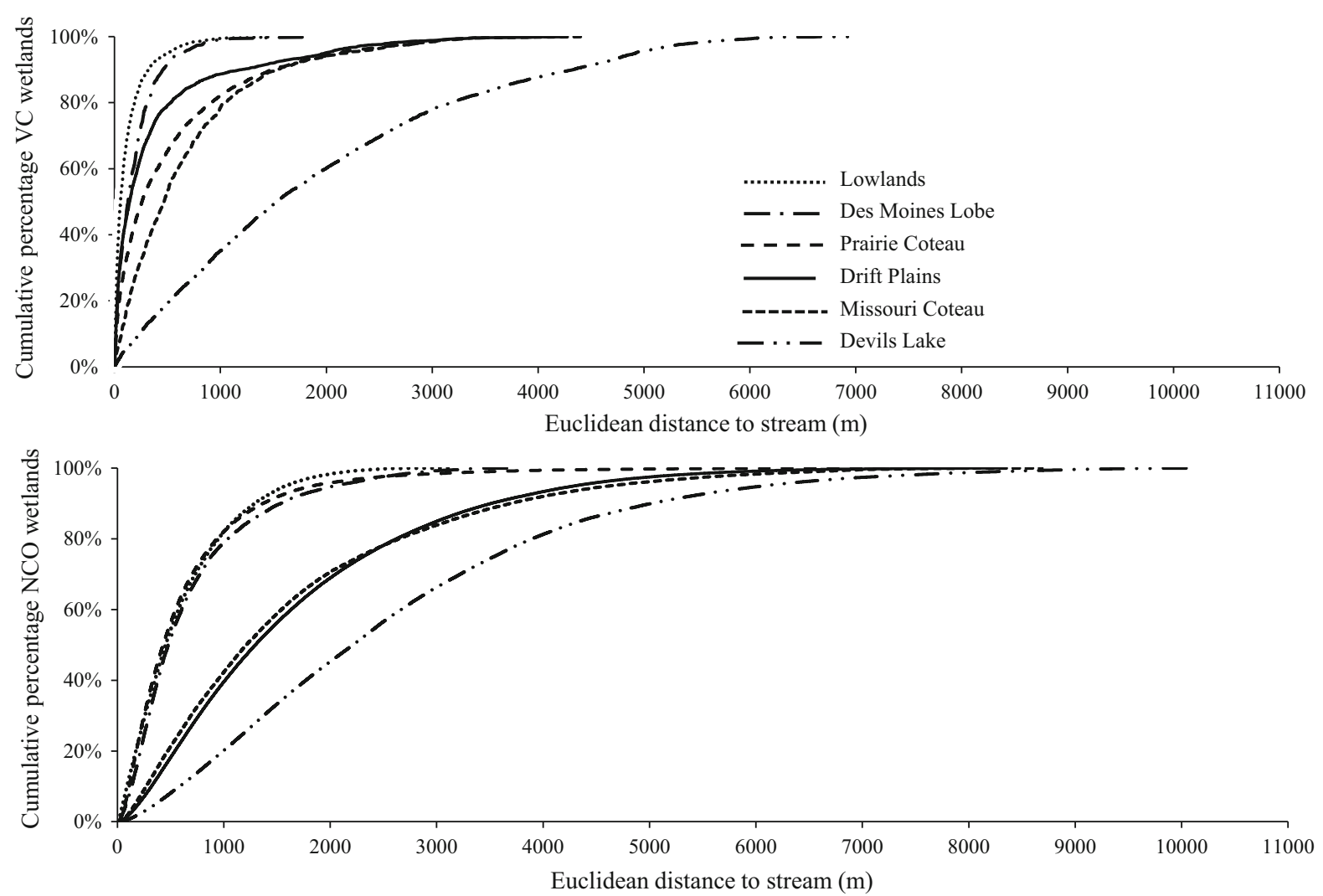

Fig. 4 Cumulative distribution function of Euclidean distance to stream for VC (variably connected) wetlands (top) relative to NCO (no connection observed) wetlands (bottom), by ecoregion

Missouri Coteau and Drift Plains ecoregions by $11,300 \mathrm{BP}$, meaning the drainage system is still developing in these ecoregions. In ecoregions with low drainage development, surface water is being stored in glacially formed depressions (Winter and Rosenberry 1998; Stokes et al. 2007), resulting in an inverse relationship between stream density and surface-water extent (Table 10). The drainage network in the PPR is also increasingly modified with the expansion of ditch networks and tile drainage in association with agricultural activities (McCauley et al. 2015). Ditches, pipes and field tiles can increase connectivity between waterbody features, however, both filling wetlands with soil and lowering the water table through increased water withdrawal can decrease expected surface-water connectivity (DeLaney 1995; Blann et al. 2009; McCauley et al. 2015). Our finding regarding the importance of predicted anthropogenic drainage may be related to the relation between land use and wetland connectivity and wetland loss (Miller et al. 2009; Van Meter and Basu 2015). These potential interrelations merit further study.

It is critical to note that the aim of this analysis was not to document all surface-water connections, recognizing limitations of our input datasets, but instead, to characterize spatial patterns for a subset of wetlands that merge with a stream over a wide range of wetness conditions and a relatively large study area. A complete analysis of wetland-to-stream connectivity would also need to consider narrow and temporary (e.g., in response to rain events and peak snow melt conditions) surface connections, groundwater connections, as well as chemical and biological connections (U.S. EPA 2015). This analysis allowed us to identify regionally relevant parameters that can provide a preliminary means to explain variability in the abundance of wetlands that affect streamflow and are subject to regulatory programs. Patterns in VC wetland abundance, for example, demonstrate that wetland abundance and arrangement in combination with 


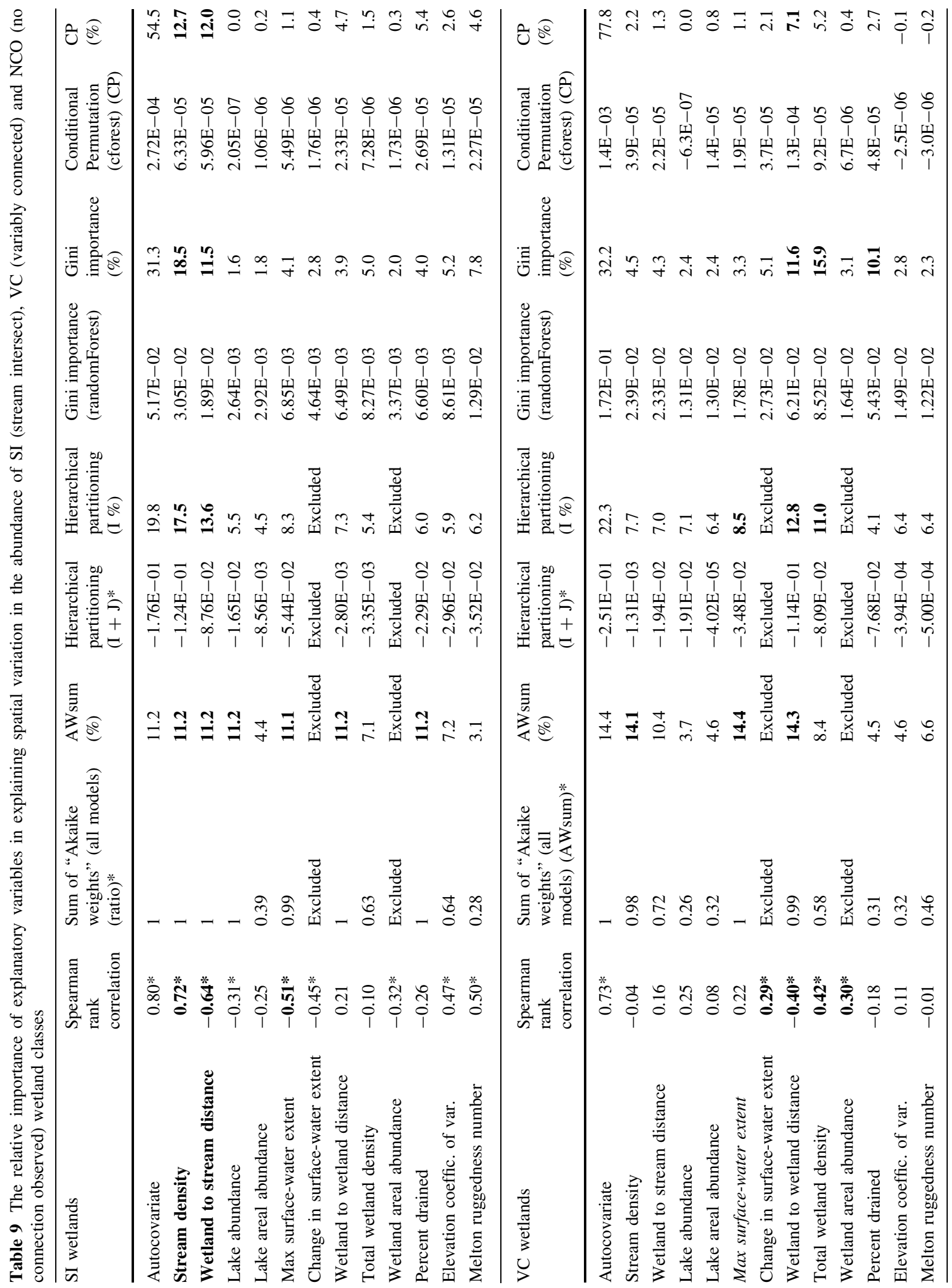




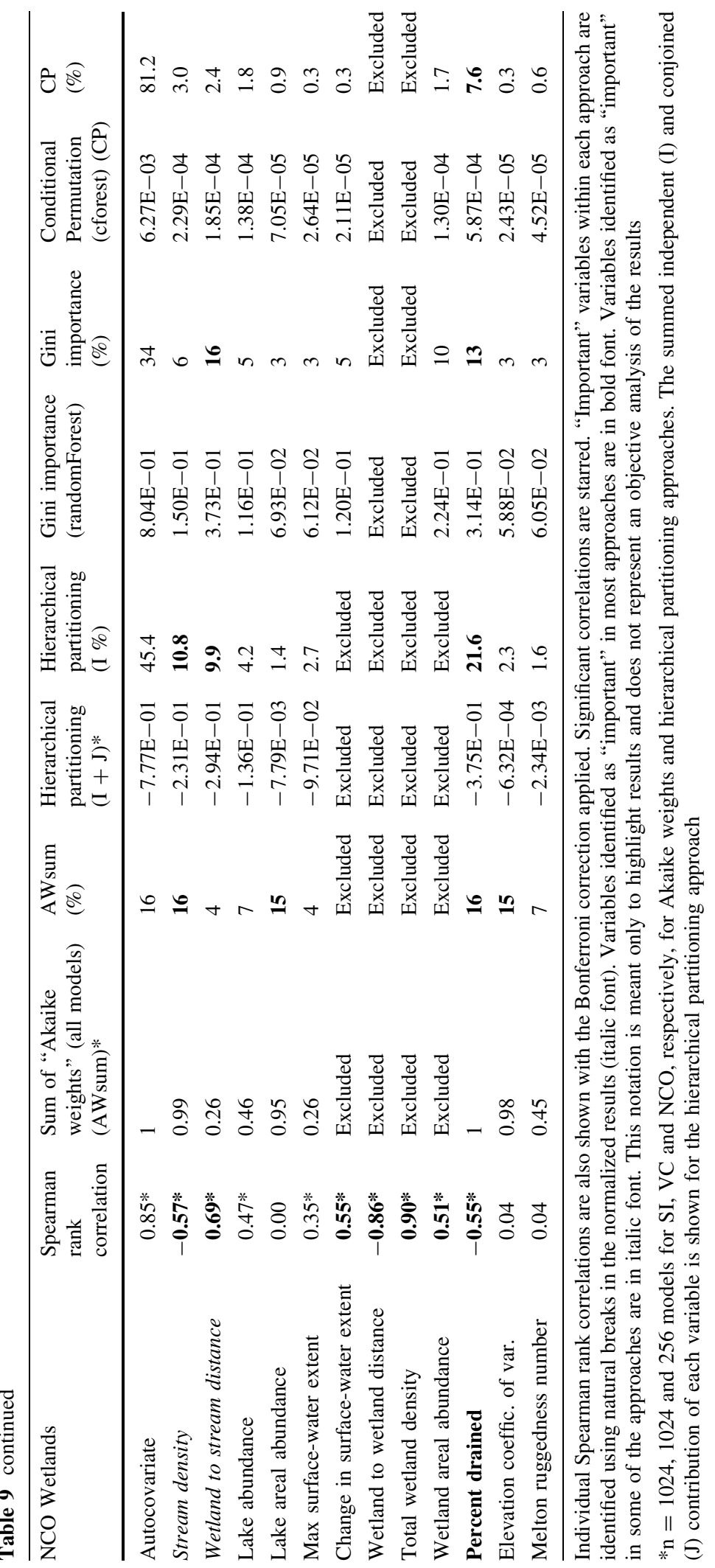




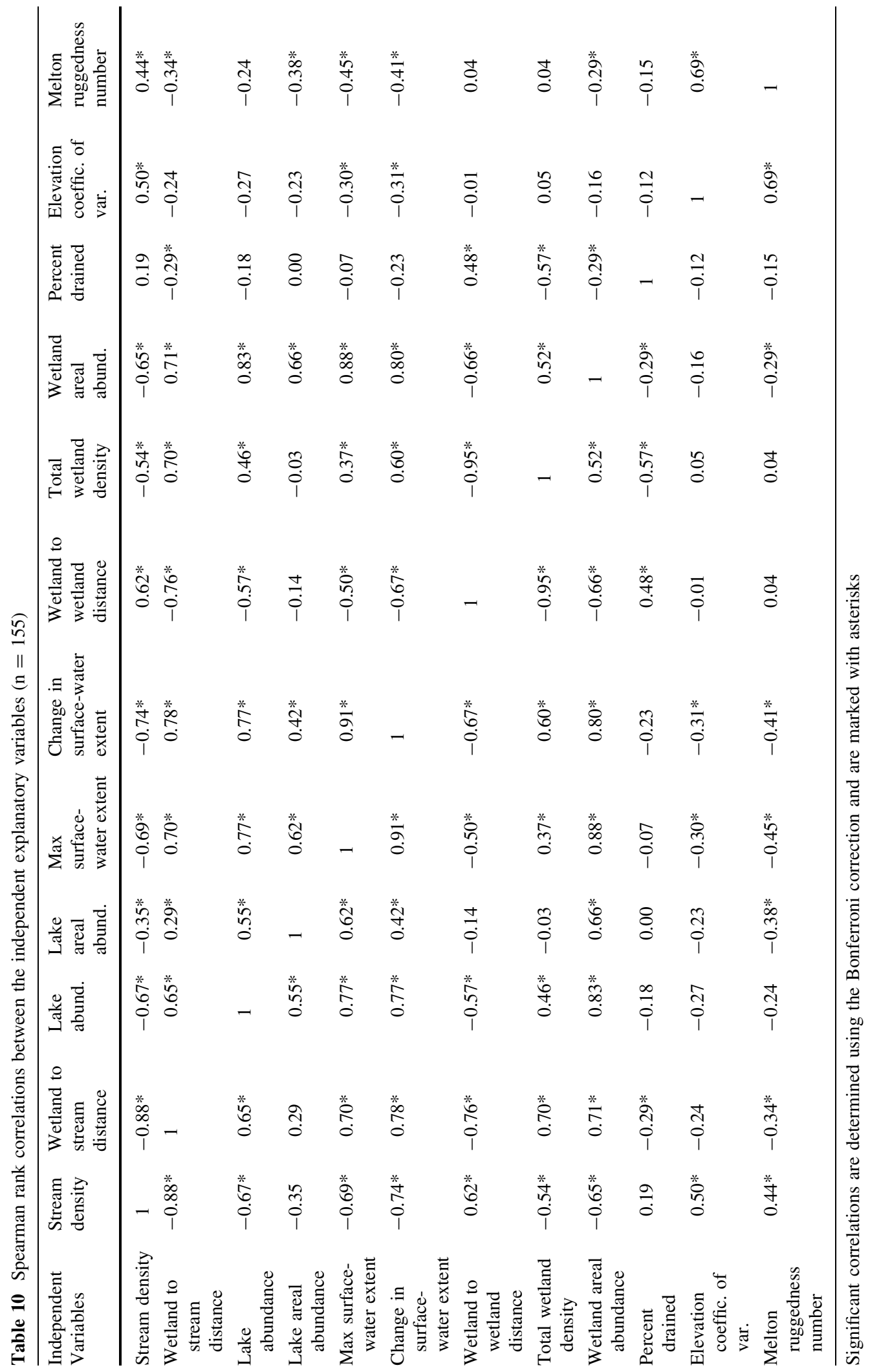




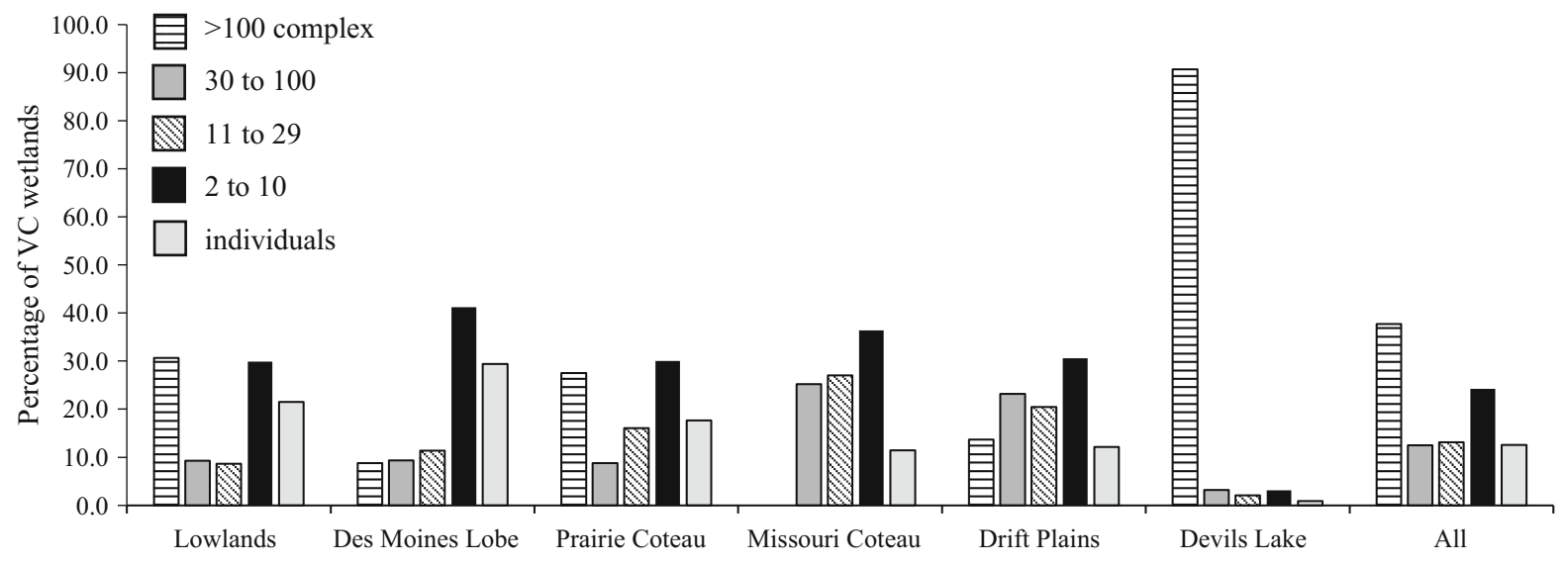

Fig. 5 The distribution of variably connected (VC) wetlands (saturated) by complex size and ecoregion under deluge conditions, or the two wettest dates per time series

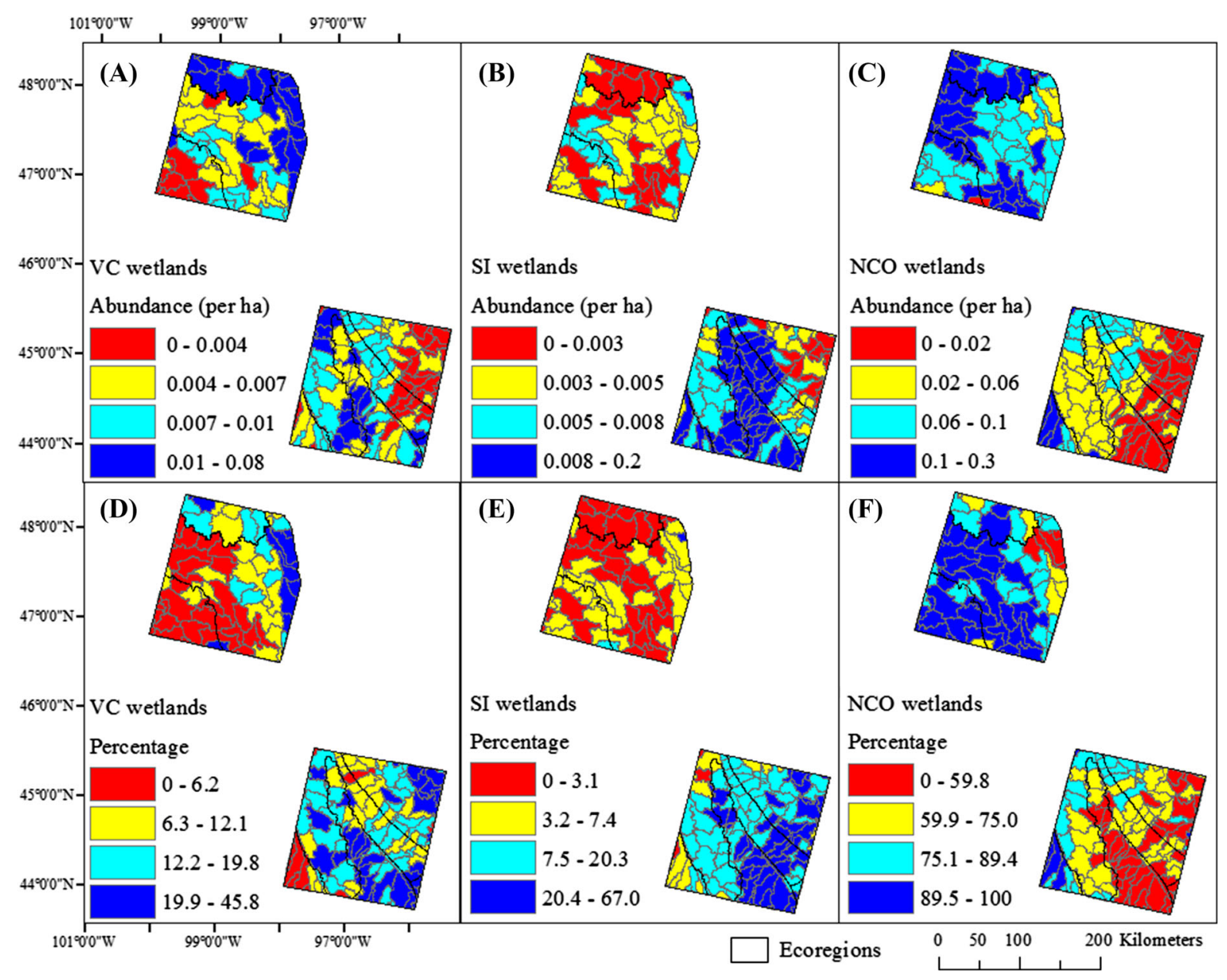

Fig. 6 Differences in the spatial pattern of VC (variably connected), SI (stream intersect), and NCO (no connection observed) wetland abundance by wetlands per ha $(\mathbf{a}, \mathbf{b}, \mathbf{c})$ and relative percentage $(\mathbf{d}, \mathbf{e}, \mathbf{f})$, where percentage is calculated from the sum of VC, SI and NCO wetlands. Category divisions represent quantiles 
expanding surface-water extent provides important opportunities for wetlands to merge with streams, a finding consistent with related literature. Limitations of this study are potential bias due to unmeasured variables and the glacial history of the landscape, which may complicate efforts to apply these variables to different ecoregions.

Further, patterns in the mechanism of connection show that in addition to SI wetlands, depressional wetlands and open waters can play critical roles in moving surface water across the landscape. These findings are particularly relevant to floodplains, permafrost landscapes and formerly glaciated landscapes that often exhibit low topographic gradients, low rates of infiltration, and low stream density. Runoff events in these landscapes rarely satisfy the threshold surface storage volume so that excess surface water (precipitation inputs exceeding soil infiltration and evapotranspiration) tends to accumulate instead of leaving the watershed as stream discharge (Hamilton et al. 2004; Yao et al. 2007; Aragón et al. 2011; Kuppel et al. 2015), leading to wetland consolidation and surfacewater connections.

\section{Conclusion}

Variably connected wetlands represent a critical subset of wetlands that may appear disconnected from streams under dry or average conditions, but exchange water and materials with streams under wetter conditions. Substantial spatial variation in the distance over which wetlands merged (or did not merge) with streams demonstrated that any characterization of connectivity based on proximity would need to be highly regionalized. More consistent across ecoregions was the mechanism of wetlands connecting to streams through wetland consolidation or wetland clusters, in particular those clusters containing an SI wetland. We documented substantial spatial variation in the relative abundance of SI, VC and NCO wetlands. The variation in abundance was best explained by different variables for each class of wetlands. However, wetland spatial arrangement, both between wetlands and between wetlands and streams, as well as the availability of surface-water connections, whether through higher stream density or larger surface-water expansion, were identified as critical to explaining the abundance of or lack of connections between wetlands and streams. Understanding the mechanisms through which wetlands merge with streams, and the spatial patterns that drive the abundance of VC wetlands in the PPR are crucial to understanding their influence on downstream waters, as well as accurately predicting flood events and the consequences of climate change on surface-water distribution, movement, and connectivity.

Acknowledgements This project was supported in part by an appointment to the Internship/Research Participation Program at the U.S. Environmental Protection Agency, Office of Research and Development, administered by the Oak Ridge Institute for Science and Education through an interagency agreement between the U.S. Department of Energy and EPA. This work was also funded by the U.S. EPA Office of Research and Development, National Center for Environmental Assessment. We thank Megan Lang and Greg McCarty at USDA for their logistical support, and Michael McManus, Ken Fritz, Chuck Lane, Jason Todd, Heather Golden, Scott Leibowitz and two anonymous reviewers for their valuable comments. The views expressed in this manuscript are solely those of the authors and do not necessarily reflect the views or policies of the U.S. EPA. Any use of trade, firm, or product names is for descriptive purposes only and does not imply endorsement by the U.S. Government.

Funding This project was supported in part by an appointment to the Internship/Research Participation Program at the U.S. Environmental Protection Agency, Office of Research and Development, administered by the Oak Ridge Institute for Science and Education through an interagency agreement between the U.S. Department of Energy and EPA. This work was also funded by the U.S. EPA Office of Research and Development, National Center for Environmental Assessment.

Open Access This article is distributed under the terms of the Creative Commons Attribution 4.0 International License (http:// creativecommons.org/licenses/by/4.0/), which permits unrestricted use, distribution, and reproduction in any medium, provided you give appropriate credit to the original author(s) and the source, provide a link to the Creative Commons license, and indicate if changes were made.

\section{References}

Ahnert F (1996) Introduction to geomorphology. Wiley, New York

Alexander LC (2015) Science at the boundaries: scientific support for the Clean Water Rule. Freshw Sci 34:1588-1594

Aragón R, Jobbágy EG, Viglizzo EF (2011) Surface and groundwater dynamics in the sedimentary plains of the Western Pampas (Argentina). Ecohydrology 4(3):433-447

Ascione A, Cinque A, Miccadei E, Villani F, Berti C (2008) The Plio-Quaternary uplift of the Apennine chain: new data 
from the analysis of topography and river valleys in Central Italy. Geomorphology 102(1):105-118

Barton K (2012) Package 'MuMIn'. Model selection and model averaging based on information criteria. $\mathrm{R}$ package version 1.7.11. R Foundation for Statistical Computing, Vienna

Beeri O, Phillips RL (2007) Tracking palustrine water seasonal and annual variability in agricultural wetland landscapes using Landsat from 1997-2005. Glob Change Biol 13:897-912

Belsley DA (1991) Conditioning diagnostics, collinearity and weak data in regression. Wiley, New York

Belsley DA, Kuh E, Welsch RE (1980) Regression diagnostics: identifying influential data and sources of collinearity. Wiley, New York

Betts MG, Ganio LM, Huso MMP, Som NA, Huettmann F, Bowman J, Wintle BA (2009) Comment on "Methods to account for spatial autocorrelation in the analysis of species distributional data: a review". Ecography 32:374-378

Blann KL, Anderson JL, Sands GR, Vondracek B (2009) Effects of agricultural drainage on aquatic ecosystems: a review. Crit Rev Environ Sci Technol 39:909-1001

Blaszczynski JS (1997) Landform characterization with geographic information systems. Am Soc Photogramm Remote Sens 63(2):183-191

Chevan A, Sutherland M (1991) Hierarchical partitioning. Am Stat 45(2):90-96

Christensen JR, Nash MS, Neale A (2013) Identifying riparian buffer effects on stream nitrogen in southeastern coastal plain watersheds. Environ Manag 52:1161-1176

Clayton L, Moran SR (1982) Chronology of late Wisconsinan glaciation in middle North America. Quat Sci Rev 1:55-82

Cohen J (1988) Statistical power analysis for the behavioral sciences, 2nd edn. Lawrence Erlbaum, Routledge

Cook BJ, Hauer FR (2007) Hydrologic connectivity on water chemistry, soils, and vegetation structure and function in an intermontane depressional wetland landscape. Wetlands 27(3):719-738

DeLaney TA (1995) Benefits to downstream flood attenuation and water quality as a result of constructed wetlands in agricultural landscapes. J Soil Water Conserv 50:620-626

Dormann CF, McPherson JM, Araujo MB, Bivand R, Bolliger J, Carl G, Davies RG, Hirzel A, Jetz W, Kissling WD, Kühn I, Ohlemüller R, Peres-Neto PR, Reineking B, Schröder B, Schurr FM, Wilson R (2007) Methods to account for spatial autocorrelation in the analysis of species distributional data: a review. Ecography 30:609-628

Esri (2013) ArcGIS Desktop: release 10.2. Environmental Systems Research Institute, Redlands

Fox J, Weisberg S (2011) An R companion to applied regression, 2nd eds. Sage, Thousand Oaks .http://socserv.socsci. mcmaster.ca/jfox/Books/Companion

Fritz KM, Hagenbuch E, D’Amico E, Reif M, Wigington PJ Jr, Leibowitz SG, Comeleo RL, Ebersole JL, Nadeau TL (2013) Comparing the extent and permanence of headwater streams from two field surveys to values from hydrologic databases and maps. J Am Water Resour Assoc (JAWRA) 49:867-882

Frohn RC, D’Amico E, Lane C, Autry B, Rhodus J, Liu H (2012) Multi-temporal sub-pixel Landsat ETM + classification of isolated wetlands in Cuyahoga County, Ohio, USA. Wetlands 32:289-299
Galat DL, Fredrickson LH, Humburg DD, Bataille KJ, Bodie JR, Dohrenwend J, Gelwicks GT, Havel JE, Helmers DL, Hooker JB, Jones JR, Knowlton MF, Kubisiak J, Mazourek J, McColpin AC, Renken RB, Semlitsch RD (1998) Flooding to restore connectivity of regulated, large-river wetlands. Bioscience 48(9):721-733

Gesch D, Oimoen M, Greenlee S, Nelson C, Steuck M, Tyler D (2002) The national elevation dataset. Photogramm Eng Remote Sens 68(1):5-11

Green AA, Berman M, Switzer P, Craig MD (1988) A transformation for ordering multispectral data in terms of image quality with implications for noise removal. IEEE Trans Geosci Remote Sens 26(1):65-74

Hamilton S, Sippel S, Melack J (2004) Seasonal inundation patterns in two large savanna floodplains of South America: the Llanos de Moxos (Bolivia) and the Llanos del Orinoco (Venezuela and Colombia). Hydrol Process 18(11):2103-2116

Hendrickx J (2012) Perturb: tools for evaluating collinearity. R package version 2.05. http://CRAN.R-project.org/ package $=$ perturb

Homer C, Dewitx J, Yang L, Jin S, Danielson P, Xian G, Coulston J, Herold N, Wickham J, Megown K (2015) Completion of the 2011 National Land Cover Database for the conterminous United States-representing a decade of land cover change information. Photogramm Eng Remote Sens 81:345-354

Hothorn T, Hornik K, Strobl C, Zeileis A (2015) A laboratory for recursive partitioning. $\mathrm{R}$ package version 1.0-25. R Foundation for Statistical Computing, Vienna

Huang S, Dahal D, Young C, Chander G, Liu S (2011a) Integration of Palmer Drought Severity Index and remote sensing data to simulate wetland water surface from 1910 to 2009 in Cottonwood Lake area, North Dakota. Remote Sens Environ 115:3377-3389

Huang S, Young C, Feng M, Heidemann K, Cushing M, Mushet DM, Liu S (2011b) Demonstration of a conceptual model for using LiDAR to improve the estimation of floodwater mitigation potential of Prairie Pothole Region Wetlands. J Hydrol 405:417-426

Junk WJ, Bayley PB, Sparks RE (1989) The flood pulse concept in river-floodplain systems. In: Dodge DP (ed) Proceedings of the international large river symposium. Can Spec Publ Fish Aquat Sci 106(1):110-127

Kahara SN, Mockler RM, Higgins KF, Chipps SR, Johnson RR (2009) Spatiotemporal patterns of wetland occurrence in the Prairie Pothole Region of eastern South Dakota. Wetlands 29(2):678-689

Kissling WD, Carl G (2008) Spatial autocorrelation and the selection of simultaneous autoregressive models. Glob Ecol Biogeogr 17(1):59-71

Kuppel S, Houspanossian J, Nosetto MD, Jobbágy EG (2015) What does it take to flood the Pampas? Lessons from a decade of strong hydrological fluctuations. Water Resour Res 51(4):2937-2950. doi:10.1002/2015WR016966

Lane CR, D'Amico E (2016) Identification of putative geographically isolated wetlands of the conterminous United States. J Am Water Resour Assoc 52(3):705-722

Lang M, McDonough O, McCarty G, Oesterling R, Wilen B (2012) Enhanced detection of wetland-stream connectivity using LiDAR. Wetlands 32:461-473 
Leibowitz SG, Vining KC (2003) Temporal connectivity in a prairie pothole complex. Wetlands 23:13-25

Liaw A, Wiener M (2015) Breiman and Cutler's random forests for classification and regression. $\mathrm{R}$ package version 4.6-12. R Foundation for Statistical Computing, Vienna

Liu G, Schwartz FW (2011) An integrated observational and model-based analysis of the hydrologic response of prairie pothole systems to variability in climate. Water Resour Res 47:W02504

Maidment D (ed) (2002) Arc Hydro: GIS for Water Resources. Esri, Redlands

Masek JG, Vermote EF, Saleous N, Wolfe R, Hall EF, Huemmrich F, Gao F, Kutler J, Teng-Kui L (2006) A Landsat surface reflectance data set for North America, 1990-2000. Geosci Remote Sens Lett 3:68-72

McCauley LA, Anteau MJ, Van Der Burg MP, Wiltermuth MT (2015) Land use and wetland drainage affect water levels and dynamics of remaining wetlands. Ecosphere 6(6):1-20

Melton MA (1965) The geomorphic and paleoclimatic significance of alluvial deposits in southern Arizona. J Geol 73:1-38

Miller BA, Crumpton WG, van der Valk AG (2009) Spatial distribution of historical wetland classes on the Des Moines Lobe Iowa. Wetlands 29(4):1146-1152

Mortsch LD (1998) Assessing the impact of climate change on the Great Lakes shoreline wetlands. Clim Change 40:391-416

Murray K, Conner MM (2009) Methods to quantify variable importance: implications for the analysis of noisy ecological data. Ecology 90(2):348-355

Niemuth ND, Wangler B, Reynolds RE (2010) Spatial and temporal variation in wet area of wetlands in the Prairie Pothole Region of North Dakota and South Dakota. Wetlands 30:1053-1064

NOAA National Climatic Data Center (2014) Data tools: 1981-2010 normals. http://www.ncdc.noaa.gov/cdo-web/ datatools/normals. Accessed 28 Oct 2014

Omernik JM, Griffith GE (2014) Ecoregions of the conterminous United States: evolution of a hierarchical spatial framework. Environ Manage 54(6):1249-1266

Philips RW, Spence C, Pomeroy JW (2011) Connectivity and runoff dynamics in heterogeneous basins. Hydrol Process 25:3061-3075

R Core Team (2014) R: A language and environment for statistical computing. R Foundation for Statistical Computing, Vienna. http://www.R-project.org/

Rains MC, Fogg GE, Harter T, Dahlgren RA, Williamson RJ (2006) The role of perched aquifers in hydrological connectivity and biogeochemical processes in vernal pool landscapes, Central Valley, California. Hydrol Process 20:1157-1175

Rains MC, Dahlgren RA, Fogg GE, Harter T, Williamson RJ (2008) Geological control of physical and chemical hydrology in California vernal pools. Wetlands 28:347-362

Rover J, Wright CK, Euliss NH Jr, Mushet DM, Wylie BK (2011) Classifying the hydrologic function of Prairie Potholes with remote sensing and GIS. Wetlands 31:319-327

Sass GZ, Creed IF (2008) Characterizing hydrodynamics on boreal landscapes using archived synthetic aperture radar imagery. Hydrol Process 22:1687-1699
Seaber PR, Kapinos FP, Knapp GL (1987) Hydrologic unit maps: U.S. Geological Survey water-supply paper 2294, 63p. http://pubs.usgs.gov/wsp/wsp2294/html/pdf.html

Shaw DA, Vanderkamp G, Conly FM, Pietroniro A, Martz L (2012) The fill-spill hydrology of prairie wetland complexes during drought and deluge. Hydrol Process 26:3147-3156

Shaw DA, Pietroniro A, Martz LW (2013) Topographic analysis for the Prairie Pothole Region of Western Canada. Hydrol Process 27:3105-3114

Sorenson L, Goldberg R, Root T, Anderson M (1998) Potential effects of global warming on waterfowl populations breeding in the northern Great Plains. Clim Change 40:343-369

Spence C, Phillips RW (2014) Refining understanding of hydrological connectivity in a boreal catchment. Hydrol Process 29(16):3491-3503. doi:10.1002/hyp.10270

Stokes CR, Popovnin V, Aleynikov A, Gurney SD, Shahgedanova M (2007) Recent glacier retreat in the Caucasus Mountains, Russia, and associated increase in supraglacial debris cover and supra-/proglacial lake development. Ann Glaciol 46(1):195-203

Strobl C, Boulesteix AL, Kneib T, Augustin T, Zeileis A (2008) Conditional variable importance for random forests. BMC Bioinform 9:307

Tiner RW (2003) Estimated extent of geographically isolated wetlands in selected areas of the United States. Wetlands 23:636-652

Tromp-van Meerveld HJ, McDonnell JJ (2006) Threshold relations in subsurface stormflow: 2. The fill and spill hypothesis. Water Resour Res 42:W02411

Turin G (1960) An introduction to matched filters. IRE Trans Inf Theory 6:311-329

U.S. EPA (2015) Connectivity of streams and wetlands to downstream waters: a review and synthesis of the scientific evidence (final report). U.S. Environmental Protection Agency, Washington, DC, EPA/600/R-14/475F. http:// cfpub.epa.gov/ncea/cfm/recordisplay.cfm?deid=296414

U.S. Fish and Wildlife Service (2010) National wetlands inventory website. U.S. Department of the Interior, Fish And Wildlife Service, Washington, DC. http://www.fws. gov/wetlands/

U.S. Geological Survey (2000) The national hydrography dataset concepts and content. http://nhd.usgs.gov/chapter1/ chp1_data_users_guide.pdf

U.S. Geological Survey (2013) The national hydrography dataset (NHD). U.S. Geological Survey, Reston, VAhttp:// nhdftp.usgs.gov/DataSets/Staged/States/FileGDB/ HighResolution/

Van Meter KJ, Basu NB (2015) Signatures of human impact: size distributions and spatial organization of wetlands in the Prairie Pothole landscape. Ecol Appl 25(2):451-465

Vanderhoof MK, Alexander LC (2015) The role of lake expansion in altering the wetland landscape of the Prairie Pothole Region. Wetlands, 1-13pp . doi: 10.1007/s13157015-0728-1

Vanderhoof MK, Alexander LC, Todd MJ (2016) Temporal and spatial patterns of wetland extent influence variability of surface water connectivity in the Prairie Pothole Region United States. Landsc Ecol 31(4):805-824 
Venables WN, Ripley BD (2002) Modern applied statistics with $\mathrm{S}, 4$ th edn. Springer, New York

Vining KC (2002) Simulation of streamflow and wetland storage, Starkweather Coulee subbasin, North Dakota. Water years 1981-1998. U.S.G.S. Water-resources investigations report 02-4113, U.S. Department of the Interior, U.S. Geological Survey in cooperation with the North Dakota State Water Commission, Bismarck, ND, 28p

Walsh C, MacNally R (2003) The hier.part package. hierarchical partitioning. $\mathrm{R}$ package version 0.5 .1. R Foundation for Statistical Computing, Vienna

Wilcox BP, Dean DD, Jacob JS, Sipocz A (2011) Evidence of surface connectivity for Texas Gulf Coast depressional Wetlands. Wetlands 31:451-458

Winter TC, Rosenberry DO (1998) Hydrology of prairie pothole wetlands during drought and deluge: 7-year study of the
Cottonwood Lake wetland complex in North Dakota in the perspective of longer term measured and proxy hydrological records. Clim Change 40:189-209

Yang W, Wang X, Liu Y, Gabor S, Boychuk L, Badiou P (2010) Simulated environmental effects of wetland restoration scenarios in a typical Canadian prairie watershed. Wetlands Ecol Manag 18:269-279

Yao T, Pu J, Lu A, Wang Y, Yu W (2007) Recent glacial retreat and its impact on hydrological processes on the Tibetan Plateau, China, and surrounding regions. Arct Antarct Alp Res 39(4):642-650

Zhang B, Schwartz FW, Liu G (2009) Systematics in the size structure of prairie pothole lakes through drought and deluge. Water Resour Res 45:W04421 